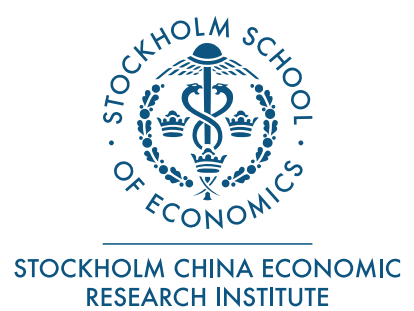

\title{
Ownership, Analyst Coverage, and Stock Synchronicity in China
}

\author{
Xunan Feng \\ Southwestern University of Finance and Economics \\ $\mathrm{Na} \mathrm{Hu}$ \\ Shanghai International Studies University \\ Anders C. Johansson \\ Stockholm School of Economics
}

\section{Stockholm School of Economics Asia Working Paper}

No. 36

July 2015 


\title{
Ownership, Analyst Coverage, and Stock Synchronicity in China
}

\author{
Xunan Feng \\ Southwestern University of Finance and Economics
}

$\mathrm{Na} \mathrm{Hu}$

Shanghai International Studies University

Anders C. Johansson ${ }^{1}$

Stockholm School of Economics

June 2015

${ }^{1}$ Corresponding author, Stockholm School of Economics, P.O. Box 6501, SE-113 83 Stockholm, Sweden. Phone: +46-8-736 9367. Fax: +46-8-31 30 17. Email: anders.johansson@hhs.se. Feng acknowledges financial support from the National Natural Science Foundation of China (71302049). 


\title{
Ownership, Analyst Coverage, and Stock Synchronicity in China
}

\begin{abstract}
This study examines how ownership structure affects the information environment of publicly traded firms in China. We hypothesize that concentrated ownership and the associated separation of ultimate control and ownership rights create agency conflicts between controlling shareholders and minority investors leading controlling owners to withhold firm-specific information from the market. We test this hypothesis by analyzing the effect of ultimate ownership structure and analyst coverage on stock return synchronicity. We find that a greater separation of control and ownership rights increases the response coefficient of stock return synchronicity to analyst coverage. This result is robust to endogeneity, a series of robustness checks, and an alternative hypothesis based on noise trading. The incentive of controlling owners to limit firm transparency thus leads analysts to disseminate more market-wide information.
\end{abstract}

Keywords: Analyst coverage; Ownership structure; Control rights; Stock synchronicity; China

JEL Classification: G14; G15; G30; G32 


\section{Introduction}

This study examines how ownership influences the information environment of publicly traded firms in China. More specifically, we study the effect of ultimate ownership structure and analyst coverage on stock return synchronicity. It is well known that ultimate owners typically have control over firms in excess of their cash flow rights. Since La Porta et al.'s (1999) pioneering study on ultimate ownership structure, this phenomenon has been documented for a range of countries and regions, including Western Europe (Faccio and Lang, 2002), East Asia (Claessens et al., 2000), and Russia (Chernykh, 2008). A general conclusion in this line of literature is that the separation of cash flow and voting rights enables controlling shareholders to extract private benefits such as excessive managerial payments, appropriation of firms' assets, and even outright theft (e.g. Shleifer and Vishny, 1997; Johnson et al., 2000; Denis and McConnell, 2003). Previous studies have shown that the resulting cost for minority shareholders is especially high in countries characterized by weak investor protection (e.g. La Porta et al.1997, 1998, 2000, 2002; Dyck and Zingales, 2004; Nenova, 2003).

Despite the fact that a growing number of studies (e.g. Faccio and Lang, 2001; Bertrand et al., 2002; Lins, 2003; Cheung et al., 2006) have examined many aspects of ultimate ownership structure and its related consequences, its effect on information dissemination in the capital markets has to a significant extent been ignored. However, the relationship between ownership and information dissemination matter for several 
reasons. First, an efficient market not only affects firm behavior, but also plays a fundamental role in the capital allocation process, thereby contributing to economic growth (Wurgler, 2000). This means that information dissemination is of importance for all economies in the long run. Second, Morck et al. (2000) analyze the information content of stock markets and find that stock prices move together more in developing economies. They conjecture that weaker legal protection against corporate insiders is associated with higher stock return synchronicity. This in turn suggests greater stock co-movements, and that less firm-specific information is incorporated in stock prices. Similarly, Jin and Myers (2006) show that stocks in countries where firms are characterized by lower transparency have higher stock return synchronicity. Their findings suggest that stronger investor protection and greater transparency facilitate the incorporation of firm-specific information into stock prices. Third, previous studies (e.g. Shleifer and Vishny, 1997; Haw et al., 2004) argue that complicated ownership structures are often associated with weak investor protection and lower transparency. Ownership structure may therefore also have a significant impact on how information is disseminated in the stock market.

China provides a unique setting for the analysis of this issue because its stock markets are characterized by weak investor protection, concentrated ownership, and a high level of stock co-movements. In addition, as the largest emerging economy in the world, China is important in its own right as it is increasingly opening its capital market to foreign investors. The results in this study can therefore provide practical 
implications not only for Chinese investors, but also for international investors that are considering investing in the Chinese market.

The closest study to ours is that of Boubaker et al. (2014). They analyze ultimate ownership and stock price synchronicity in the French market. However, their study does not take analyst coverage into consideration. As an important intermediary between firms and investors, analysts specialize in collecting and processing industryand market-level information (O'Brien and Bhushan, 1990; Clement, 1999; Jacob et al., 1999; Ramnath, 2002). Analysts also convey firm-specific news (Admati and Pfleiderer, 1986; Diamond and Verrecchia, 1981; Chung and Jo, 1996), thereby alleviating information asymmetry and improving the efficiency of the information flow. There are a few studies on analyst coverage and stock price synchronicity. For example, Piotroski and Roulstone (2004) find that analyst coverage is positively associated with stock return, meaning that analyst following leads to more market-wide information being incorporated in stock prices. While previous research has shown that this pattern is much more prevalent in emerging markets (Chan and Hameed, 2006), few studies have explored its underlying mechanisms. Emerging markets are characterized by concentrated ownership, and the institutional setting typically allows the controlling owners to expropriate minority investors (Lins, 2003; Khannaand Yafeh, 2007). If the private benefits of control are substantial, ultimate owners will have little incentive to voluntarily disclose firm-specific information and enhance corporate transparency. Instead, they are more likely to conceal evidence of 
"tunneling". Consequently, firm opacity is typically substantial, resulting in difficulties when it comes to obtaining true information from such firms. We therefore argue that it is relevant to analyze how ultimate ownership structure affects information dissemination by analysts.

Using a unique data set from China for the period 2005-2012, we study the relationship between ultimate ownership, analyst coverage, and stock return synchronicity. We find that, conditioned on the same level of analyst coverage, the more voting rights exceed cash flow rights, the greater stock return synchronicity. This result is robust to endogeneity tests. It also holds up to a series of additional robustness checks, including test in which we consider family versus state ownership, market conditions, and ownership structure in the form of pyramidal schemes, a specific control-enhancing means to separate voting and cash flow rights. Finally, we also rule out an alternative explanation for our results based on noise trading.

This study makes several contributions to the literature. First, it adds to two strands of literature by linking ultimate ownership and stock co-movements. Although the economic consequences of ultimate ownership have been extensively examined, its impact on information dissemination in capital markets has been largely ignored. On the other hand, while the positive relationship between stock return synchronicity and analyst coverage is greatly acknowledged, few studies investigate the underlying reason. We aim to combine these two strands of literature, as we believe that low firm transparency due to controlling owners with a high degree of separation between 
ownership and control rights exacerbates analyst-driven stock co-movements.

Second, we contribute to the small but bourgeoning literature on Chinese analysts. As an emerging market and rapidly growing economy, China has witnessed a dramatic increase in analysts, from none at the establishment of the stock market in 1990s to 1,215 as of 2011. ${ }^{1}$ Chen et al. (2015) argue that analysts serve as an external governance mechanism by reducing the propensity to issue modified audit opinions. However, the low quality of analyst reports has also been criticized in Chinese media (e.g. Sun and Peng, 2010; Wu and Pan, 2011; Zhang, 2011; Qu et al., 2014). Gu et al. (2013) and Lin et al. (2013) find that securities analysts fail to issue reports independently and objectively due to distorted incentives. Our finding, that analyst coverage mainly facilitates market-level information dissemination, especially for firms with complicated ownership, sheds further light on the analyst industry in China.

The rest of this study proceeds as follows. The next section discusses the institutional background and develops the hypothesis. Section 3 presents the data sample, introduces the variables and also provides descriptive statistics. Section 4 presents the empirical results. In addition to the baseline results, it also presents an attempt to deal with endogeneity issues as well as a battery of additional robustness checks. Section 5 discusses and analyzes the alternative noise-trading argument.

\footnotetext{
${ }^{1}$ The number of registered analysts can be retrieved from Securities Association of China (http://www.sac.net.cn/).
} 
Finally, Section 6 concludes the study.

\section{Institutional Background, Related Literature and Hypothesis Development}

\subsection{Institutional Background}

\subsubsection{Analysts in China}

Since China formally established its stock market in early 1990s, a great number of investors have flooded into the market, triggering an urgent demand for information intermediaries such as financial analysts. During the first period from 1991 to 1997, financial analysts, typically called security consultants at that time, began to provide investors with information on government policies, technical analysis, firm prospects, and stock recommendations. Lacking a regulatory and supervisory framework, some analysts tended to exaggerate their recommendations. Moreover, research reports based on fundamental analysis were rarely provided to investors. This early stage of the Chinese analyst industry was thus characterized by underdevelopment, immaturity, and disarray.

As a response to the weak development of the analyst industry, the Securities Analysts Association of China (SAAC) was established in July 2000. The formation of SAAC, a self-regulatory organization, marked a milestone in the development of the analyst industry in China. At this time the "Code of Ethics and Standards for 
Analysts", which regulate analyst conduct was also published for the first time. As a result of these attempts to clean up the industry, graduates and MBAs from top universities in the country began to join the industry and the overall level of analyst professionalism improved significantly. Nevertheless, cleaning up and improving the quality of the industry is a long-term effort, and misconduct and transgressions by securities analysts are still revealed from time to time.

China's entry into the WTO in 2001 and the launch of the Qualified Foreign Institutional Investors (QFII) program in 2002 marked a new phase for Chinese analysts, as fundamental analysis was now in urgent demand. Moreover, the explosive development of the Chinese mutual fund industry further accelerated this trend. Similar to their U.S. counterparts, Chinese analysts now began to conduct frequent corporate visits, telephone conferences, and road shows for institutional investors. The number of registered analysts reached 1,215 at the end of 2011 with a publication of 162,357 reports in that year alone (SAC, 2012). A direct and negative effect of the fierce career competition in the Chinese analyst industry is that it compels analysts to issue reports frequently and quickly, often leading to poor quality analyses.

\subsubsection{Publicly-traded Companies and Ultimate Owners}

In contrast to the stock market in the U.S., China's stock market was born at the early stages of economic reforms in which the economic system was slowly transitioning from a planned economy to a market economy. As a result, it is 
characterized by several salient features, including concentrated ownership and state ownership. Due to ideological objectives, the private sector in China has developed on an uneven playing field. Private entrepreneurs have been socially and politically discriminated and various political movements have cracked down upon them on a regular basis during the early stages of reform (Li et al., 2008). For a long time, a majority of private firms were not even eligible for public offerings due to a strict listing quota system (Pistor and $\mathrm{Xu}, 2005$ ). Two additional stock exchanges, the SME Board $^{2}$ and ChiNext ${ }^{3}$, were launched in 2004 and 2009 in an effort to provide alternative channels for private firms to go public. However, state ownership still remains a key characteristic of the Chinese stock market. For example, according to the State-owned Assets Supervision and Administration Commission of the State Council (SASAC), 953 state-owned enterprises (SOEs) accounted for $38.5 \%$ of the total number of listed firms, while their market capitalization reached $\$ 2.18$ trillion, corresponding to $51.4 \%$ of the total value of the Shanghai and Shenzhen stock markets at the end of 2012 .

\footnotetext{
${ }^{2}$ China's SME board is a sub-board of the Shenzhen Stock Exchange for the listing of small and medium-sized enterprises (SMEs).

${ }^{3}$ ChiNext is a NASDAQ-style board of the Shenzhen Stock Exchange, aiming to attract innovative and fast-growing enterprises, especially high-tech firms.
} 


\subsection{Related Literature and Hypothesis Development}

In contrast to Berle and Means' classic image of widely held firms, many studies have revealed a high level of concentration of ownership in stock markets around the world. ${ }^{4}$ Based on these findings, La Porta et al. (1999) trace the chain of ownership and answer two important questions: Who ultimately controls the publicly traded firms around the world and how do ultimate shareholders excise that control? They find that controlling shareholders - usually the state or families - are present in most companies. These shareholders have control rights in firms in excess of their cash flow rights, largely through the use of pyramids and direct participation in the management of the firms. Consequently, this form of ownership structure creates opportunities, gives powers and provides incentives for controlling shareholders to expropriate minority investors. A large body of subsequent research discusses the consequences of this form of ownership structure, including dividend payout (Faccio and Lang, 2001), value-destroying acquisitions (Baeket al., 2006; Masulis et al., 2009), tunneling (Bertrand et al., 2002; Johnson et al., 2000), management turnover (Volpin, 2002), securities issuing (Bae et al., 2006), debt financing (Boubakri and Ghouma, 2010), investment (Wei and Zhang, 2008), firm value (Claessens et al., 2000; Lins, 2003; La Porta et al., 2002) and control premium (Dyck and Zingales, 2004;

\footnotetext{
${ }^{4}$ Examples include the U.S. (Holderness and Sheehan, 1988; Morck et al., 1988), Germany (Franks and Mayer, 2001; Gorton and Schmid, 2000), Japan (Berglof and Perotti, 1994), OECD countries (European Corporate Governance Network, 1997), Israel (Blass et al., 1998), Malaysia (Hui, 1981).
} 
Nenova, 2003). All of these studies corroborate Shleifer and Vishny's (1997) argument that a key agency problem in public firms is the expropriation of outside investors by controlling shareholders. Since controlling owners tightly control firms, and implement or closely oversee the information disclosure, opacity is a good strategy since it can prevent firm-specific information leakage to the market, so that the controlling owners may avoid unwanted scrutiny.

Empirical evidence shows that concentrated ownership and the associated wedge between cash flow and control rights cause reported earnings to lose credibility to outside investors (Fan and Wong, 2002). Leuz et al. (2003) and Haw et al. (2004) also find that earnings management is positively related to the size of private control benefits enjoyed by insiders. The information asymmetry between controlling shareholders and minority investors can also be reflected in the stock market. For example, Attig et al. (2006) find that stocks of firms with greater deviations between ultimate control and ownership have a larger information asymmetry component in their bid-ask spread. Summing up, these studies suggest a lower quality of accounting information for firms characterized by a larger divergence between ownership and control rights.

Analysts exist mainly because of their roles in disseminating information. But how do they perform when analyzing firms with lower transparency? Ideally, a greater information demand for such firms may incentivize analysts to identify and publish more firm-specific information, especially if information at the firm level can 
be obtained at zero or low cost. However, analysts do not work in a vacuum. Many studies argue that analysts consciously bias recommendations upwards in an effort to please corporate management. This is because management often "freeze out" analysts who fail to issue favorable recommendations (Francis et al., 1997; Chen and Matsumoto, 2006). Considering that controlling owners have a decisive power in deciding who can access firm-specific information, this potential threat becomes increasingly challenging for those analysts who follow firms characterized by a larger discrepancy between ownership and control rights. The effect of analyst coverage on information dissemination for such firms therefore deserves special attention.

Piotroski and Roulstone (2004) and Chan and Hameed (2006) discuss the relationship between analyst coverage and firm-specific information dissemination, proxied by stock return synchronicity, in the U.S. and emerging markets. They find that analyst coverage accelerates the dissemination of market-wide, rather than firm-specific, information. We push this discussion further and study how the ultimate ownership structure affects the relationship between analyst coverage and stock return synchronicity. If opacity induced by private control benefits of ultimate owners impedes firm-specific information dissemination, then our main hypothesis is as follows:

Main Hypothesis: Stock return synchronicity is positively associated with analyst coverage, especially for firms characterized by a larger gap between ownership and control rights. 


\section{Data Sample and Variables}

\subsection{Data Sources}

Our sample includes all publicly traded firms with A-shares on the Shanghai and Shenzhen stock exchanges between 2005 and 2012. ${ }^{5}$ The sample starts from 2005 because most data vendors began to provide analyst coverage information around this year. Data from before 2005 is incomplete and large discrepancies also exist due to the immaturity of the analyst industry as well as incomparable data processing procedures.

We obtain analyst coverage from Gildata, which provides the most comprehensive analyst data for China. ${ }^{6}$ In contrast to other vendors, it also includes

${ }^{5}$ Firms have issued A- and B-shares since the opening of the two Chinese stock exchanges. Domestic investors are allowed to trade A-shares, while foreign investors originally traded B-shares. After a comprehensive stock market reform in 2001, domestic investors are now also allowed to trade in B-shares. Only a minority of the firms on the Shanghai and Shenzhen stock exchanges have issued B-shares. Moreover, the Chinese government has also introduced reforms to gradually open up the A-share market to foreign investors. Foreign investors are now allowed to invest in A-shares if they are eligible for the so-called Qualified Foreign Institutional Investor (QFII) scheme. For more information on the different share classes in China, see Chan et al. $(2007,2008)$.

${ }^{6}$ Gildata is a database that is affiliated with Hundsun Technologies Inc., a publicly-traded company in China. 
full-texts of each analyst report. Having randomly reviewed 100 sample reports, we are sufficiently confident in the quality of the data. Stock return and financial data is obtained from the China Security Market and Accounting Research (CSMAR) database. Finally, we extract mutual funds data from the WIND database.

\subsection{Construction of Variables}

\subsubsection{Ultimate Ownership and Control Rights}

It has been pointed out that many Chinese listed firms are characterized by a single dominant shareholder that holds a much larger proportion of shares of the company compared to the second largest shareholder (Chen et al., 2009). Following previous studies (e.g. Chen et al., 2009, Feng et al., 2014), we therefore focus on the controlling shareholders and categorize listed firms into privately or state-controlled based on their ultimate shareholders. This information is manually collected from annual reports. ${ }^{7}$ Regulations set up by the China Securities Regulatory Commission (CSRC) state that listed firms must publicly disclose information on ultimate owners

\footnotetext{
${ }^{7}$ Ownership structure is typically relatively stable, and most studies assume no change over time. However, to assume that ultimate owners change more frequently in a transition economy is not particularly farfetched. For example, Huang et al. (2013) discuss the large-scale 're-nationalization' in China, resulting in significant changes in ultimate ownership. We therefore follow each firm and collect their ultimate ownership information year by year.
} 
since $2001 .^{8}$ This rule was strengthened in 2004, which simplifies the identification of ultimate owners for this study. Following La Porta et al. (1999) and Claessens et al. (2000), we focus on ultimate ownership and control patterns. In most cases, the immediate shareholders of publicly-traded firms are corporate entities. We then identify their owners, the owners behind those owners, and so on, and finally find out ultimate owners. Ultimate owners are identified either as individuals or the state. ${ }^{9}$

Ownership is measured as the cash flow rights, which is the fraction of the dividends paid by a firm that is eventually received by the ultimate owner. Control is defined as the voting rights. ${ }^{10}$ Suppose that a family owns 60 percent of the stock of firm B, which in turn holds 30 percent of the stock of a publicly traded firm A.

${ }^{8}$ See article 25 in "Notice of the China Securities Regulatory Commission on Promulgating the Standards Concerning the Contents and Formats of Information Disclosure by Companies Offering Securities to the Public No.2 — Contents and Formats of Annual Reports” (2001 Revision).

${ }^{9}$ Ownership by individual family members is not considered as separate ownership. We instead use total ownership by each family as a group of people related by blood or marriage (Claessens et al., 2002).

${ }^{10}$ Following La Porta et al. (1999), to determine effective control at any intermediate levels as well as the ultimate level, we use a cutoff point above which we assume that the largest shareholder has effective control over the intermediate and final firms. $10 \%$ is used as the cutoff point in this study. The results remain qualitatively the same when we use $20 \%$ as the cutoff point. 
According to La Porta et al. (1999), this family owns the product of two ownership stakes along the chain, or about 18 percent of the cash-flow rights of firm A. The family also controls 30 percent of firm A, the weakest link along the chain of control rights. (Control - Ownership) is used to proxy for the ultimate owner's control in excess of their cash flow rights, defined as the difference between Control and Ownership. Following the discussion on separation of ownership and control in Section 2.2, larger (Control - Ownership) indicates stronger incentives for controlling owners to expropriate minority investors.

In other countries, multiple mechanisms to enhance ultimate owners' power such as cross-holdings and deviations from one-share-one-vote through shares with different voting rights are typically used. In China on the other hand, pyramid structures are particularly popular. Pyramid ownership is when an owner controls one firm which in turn controls another firm, a process that can be repeated numerous times. To shed light on ownership of listed companies in China, we present some examples of ownership structures. These examples are obtained from 2012 annual reports. Figure 1 shows the ultimate ownership structure of China Construction, a leading construction and real estate conglomerate. SASAC, representing the state, holds $100 \%$ of the votes as well as shares of China State Construction Engineering Corp., which in turn owns 51.28 percent of China Construction. This is a typical pyramidal structure without separation of control and ownership rights. Next, Figure 2 describes Orient Zirconic, which is directly controlled by its founder Chaodian Chen. 
Naturally, no pyramid is used in this case as the firm is directly owned and controlled by its founder. Finally, Figure 3 illustrates the ownership structure of Nanjing Iron \& Steel Co., Ltd. The firm is ultimately controlled by Guangchang Guo, a well-known entrepreneur, through a complicated pyramidal structure. The ultimate ownership is thus $23.06 \%$, and the ultimate control rights amounts to $58 \%$.

[Figure 1 here]

[Figure 2 here]

[Figure 3 here]

\subsubsection{Stock Return Synchronicity}

Our measure of stock return synchronicity follows Morck et al. (2000). We obtain $R^{2}$ from the following expanded index model:

$$
\begin{gathered}
r_{i, t}=\alpha+\beta_{m, t} r_{m, t}+\beta_{I N D, t} t_{I N D, t}+\beta_{m, t+1} r_{m, t+1}+\beta_{I N D, t+1} r_{I N D, t+1} \\
+\beta_{m, t-1} r_{m, t-1}+\beta_{I N D, t-1} r_{I N D, t-1}+\varepsilon_{i, t}
\end{gathered}
$$

where $r_{i, t}$ is the return of stock $i$ in week $t ; r_{m, t}$ is the market return in week $t$, calculated as the weekly tradable market value-weighted returns of all A-share stocks on the Shanghai and Shenzhen stock exchanges; and $r_{I N D, t}$ is the industry return in week $t$, calculated as the tradable market value-weighted industry index, excluding firm $i$. By including lead and lag terms for the market and industry indexes, we also take non-synchronous trading into account (Dimson, 1979). ${ }^{11}$

\footnotetext{
${ }^{11}$ Ignoring potential non-synchronous trading does not change our main findings.
} 
$R^{2}$ is the coefficient of determination from the above estimation. Because it ranges between 0 and 1, we follow Morck et al. (2000) and define stock return synchronicity by using a logistic transformation:

$$
\text { Synch }=\operatorname{LOG}\left(R^{2} /\left(1-R^{2}\right)\right) .
$$

$R^{2}$ is the fraction of variation in firm i's returns explained by market and industry factors. A high value of Synch thus indicates that less firm-specific information is impounded into the stock return (e.g. Roll, 1988; Morck et al., 2000). This $R^{2}$-based inefficiency measure has been used in various empirical studies on corporate investment and emerging markets (e.g. Wurgler, 2000; Durnev et al., 2003; Durnev et al., 2004; Jin and Myers, 2006; Chen et al., 2006).

Table 1 presents the descriptive analysis of stock return synchronicity and $R^{2}$. On average, $36.4 \%$ of stock returns can be explained by market-wide factors in our sample. This is considerably higher than $2.1 \%$ for U.S., $6.2 \%$ for U.K., $15 \%$ for Hong Kong, and $17 \%$ for Korea in Morck et al.'s (2000) study. ${ }^{12}$ This initial finding indicates much higher stock co-movements in China. Panel A in Table 1 illustrates Synch and $R^{2}$ by year. As can be seen, the measures change considerably over time. Panel 2 describes Synch and $R^{2}$ by industry according to CSRC classification standards (2001 Revision). ${ }^{13}$ We can see that $R^{2}$ is higher for the finance, mining, and

\footnotetext{
${ }^{12} R^{2}$ for China in Morck et al. (2000) was $45.3 \%$.

${ }^{13} \mathrm{CSRC}$ revised the industry classification in December, 2012. Most IPO firms in this study went public before the revision and we therefore use the 2001 version of CSRC industry standards. As a very
} 
transportation industries, and lowest for the pharmaceutical industry. The $R^{2}$ for the pharmaceutical industry is still high at 0.312 , again suggesting very high stock co-movements in China.

[Table 1 here]

Appendices 1 and 2 provide the definitions of the main variables as well as their descriptive statistics. The correlation coefficients between the variables are presented in Appendix 3.

\section{Empirical Results}

\subsection{Descriptive Statistics}

Panel 1 in Table 2 presents the univariate statistics of stock return synchronicity and analyst coverage. As in related studies, analyst coverage is defined as the average number of analysts who publish earnings forecasts for the firm during a year. Some firms are not covered by analysts. We place these firms in a zero-analyst subsample. For completeness, we include this subsample in our analysis, but the results hold when they are excluded from the analysis.

We divide the rest of the sample into three groups each year based on the number of analysts that provide coverage, and then present the mean (median) value of $R^{2}$ and

large number of firms are clustered in the manufacturing industry, we use the second digit in the classification scheme to separate industries further. 
Synch by calculating their time series average (median) of cross-section average (median) value for each subsample. The number of firm-year observations is 4,276, $2,289,2,743$, and 2,605 for the zero, low, medium and high subsample, respectively. On average, there are $1.73,7.97$, and 35.29 analysts covering firms in the second, third, and fourth groups, respectively. The median value of analyst coverage is 2,7 and 29 , respectively.

It is evident from this panel that stock return synchronicity tends to increase for firms characterized by a larger analyst following. The average $R^{2}$ statistics are 0.346 , $0.370,0.376$, and 0.386 , and the synchronicity measures are $-0.339,-0.278,-0.261$, and -0.247 for the groups with zero, low, medium, and high numbers of analysts, respectively. The corresponding median values exhibit similar patterns. Both the T-test and the Wilcoxon-Mann-Whitney test show that there is a significant difference in $R 2$ or Synch between the zero and high analyst coverage subsamples at the one percent level. While these findings only constitute a preliminary univariate analysis, they are consistent with the argument made by Piotroski and Roulstone (2004) and Chan and Hameed (2006), namely that more analyst coverage primarily facilitates market-wide information dissemination.

We next discuss the relationship between ultimate ownership structure and stock return synchronicity. Firms with the same control and ownership rights are classified as a separate portfolio, while the remaining firms are sorted into three tertiles each year. The average and median (in parenthesis) values of $R^{2}$ and Synch for each 
portfolio are presented in Panel B in Table 2. On average, $R^{2}$ is $0.348,0.356,0.384$ and 0.402 for the zero, low, medium and high (Control - Ownership) portfolios, respectively. Similarly, Synch is monotonically increasing in (Control - Ownership). Both the $T$-test and the Mann-Whitney-Wilcoxon test indicate that $R^{2}$ and Synch for firms with high (Control - Ownership) are significantly larger than firms with low (Control - Ownership) at the one percent level.

[Table 2 here]

\subsection{Multivariate Regression Results}

The initial univariate analysis in the preceding section suggests that there is a significant relationship between stock synchronicity and analyst coverage as well as ownership structure. To strengthen these results, we now carry out a multivariate analysis to control for a range of other firm-specific factors that may influence stock synchronicity. We use the following multivariate regression model:

$$
\begin{aligned}
\text { Synch }_{i, t}=\beta_{0}+\beta_{1} & \log \left(1+\text { Analyst }_{i, t}+\beta_{2}\left(\text { Control }-{\text { Ownership })_{i, t}}+\beta_{3}\left({\text { Control }- \text { Ownership }_{i, t}}\right.\right.\right. \\
& * \log \left(1+\text { Analyst }_{i, t}+\beta_{4} \text { Size }_{i, t}+\beta_{5} \text { Leverage }_{i, t}+\beta_{6} \text { Segments }_{i, t}+\beta_{7} \text { Ownership }_{i, t}\right. \\
& +\beta_{8} \text { Volume }_{i, t}+\beta_{9} \text { Volatility }_{i, t}+\beta_{10} \text { Illiquidity }_{i, t}+\beta_{11} \text { INST }_{i, t} \\
& +\beta_{12} \text { Investibility }_{i, t}+\beta_{13} \text { HHI }_{i, t}+\beta_{14} \text { SynchronousFundamentals }_{i, t} \\
& +\sum_{m} \text { Industry }_{m}+\sum_{n} \text { Year }_{n}+\varepsilon_{i, t}
\end{aligned}
$$

where $i$ represents the firm and $t$ represents the year in question. $\log (1+$ Analyst $)$ is defined as the natural logarithm of one plus the number of analysts 
that cover firm $i$ at year $t$. The key variable in this study is the interaction variable $($ Control - Ownership)* $\log (1+$ Analyst). If firms with a large gap between control and ownership rights enable their controlling owners to expropriate minority investors, these controlling owners are likely striving for a higher level of corporate opacity to facilitate expropriation of funds. This will in turn hinder analysts in their pursuit to collect and analyze firm-level information, and thus increase stock return synchronicity. The coefficient of (Control - Ownership)*Log $(1+$ Analyst) is therefore expected to be positive.

Control variables in the multivariate analysis include: Size, defined as the natural logarithm of the market value of equity at the beginning of year $t$; Leverage, defined as the book value of all liabilities scaled by total assets, measured at the beginning of the year $t$; Segments, the number of segments, including only those in which sales exceed $30 \%$ of firm i's total sales at the beginning of the year $t$; Ownership, defined as the cash flow rights of the ultimate owner at the beginning of the year $t$; Volume, defined as the natural logarithm of the trading volume in renminbi (RMB) of firm $i$ in year $t$; Volatility, defined as the standard deviation of the stock return of firm $i$ in year t; Illiquidity, defined as the average ratio of daily absolute returns to the daily trading volume in year $t$, multiplied by $10^{9}$; \%INST, defined as the ratio of mutual funds' holdings, measured as the aggregate number of shares held by mutual funds, scaled by outstanding shares of firm $i$ at the beginning of year $t$; Investibility, defined as the free float percentage of firm $i$ at the beginning of year $t$ available to public investors; $H H I$ 
(Herfindahl-Hirschman Index), an indicator of competition, estimated using all listed firms' sales from the same industry at the beginning of year $t$; Synchronous fundamentals, defined as the Spearman correlation between the firm's ROA and its industrial average ROA over the past ten quarters. Industry and year fixed effects are also included. All continuous variables are winsorized at the top and bottom $1 \%$ to alleviate the effect of outliers.

Column 1 in Table 3 presents the pooled OLS regression over the full sample period 2005-2012. All $t$-statistics are based on heteroskedasticity-consistent standard errors with clustering by industry and year (Petersen, 2009; Thompson, 2011). Consistent with the preliminary results in the previous section, Log $(1+$ Analyst $)$ is significantly (at the five percent level) and positively associated with the stock return synchronicity, supporting the argument that security analysts predominantly produce market-wide information (Piotroski and Roulstone, 2004; Chan and Hameed, 2006). On average, a one standard deviation increase in $\log (1+$ Analyst $)$ results in an increase of $1.1 \%\left(1.369^{*} 0.008\right)$ in stock price synchronicity. The coefficient of (Control - Ownership) is also positive, but it is no longer significant at the conventional level. Turning to the interaction term of (Control - Ownership) and $\log (1+$ Analyst $)$, we find that it is positively and significantly related with stock return synchronicity. This suggests that, conditioned on the same level of analyst coverage, a larger gap between control and ownership rights constrain the dissemination of firm-specific information. 
A potential concern with the pooled OLS model is the cross-sectional dependence which can result in biased standard errors and lead us to make incorrect inferences. To alleviate this concern, we use Fama and MacBeth's (1973) two-step procedure, and include industry fixed effects to check its robustness. Specifically, we perform a cross-sectional regression for each year and then compute a time-series average of the estimated coefficients. T-statistics are calculated using heteroskedasticity- and autocorrelation-consistent Newey-West (1987) standard errors. Column 2 in Table 3 presents these new panel regression results. The regression coefficient of the interaction of (Control - Ownership) and $\log (1+$ Analyst $)$ is once more positive and significant. This finding lend further support to the hypothesis that firms characterized by a greater separation of control and ownership rights are more likely to make their firms more opaque and reveal less firm-specific information to the market.

[Table 3 here]

\subsection{Endogeneity}

The analysis of analyst coverage in the previous section ignores the fact that analysts are not randomly assigned to firms. For example, analysts initiate/terminate their coverage endogenously, and the decision whether or not to cover a firm could result in a relationship between analyst coverage and stock return synchronicity. To deal with this potential problem of endogeneity, we carry out an instrumental variable two-stage least square regression analysis. In the first stage, we use a pooled Tobit 
model with $\log (1+$ Analyst $)$ as the dependent variable and again apply heteroskedasticity-robust standard errors clustered by firm. In the second-stage regression, we then include the predicted $\log (1+$ Analyst $)$ as an independent variable.

Panel A in Table 4 provides summary statistics for the instrument variables used in the first-stage regression: CSI 300, an indicator for whether the firm is a constituent stock of CSI 300, a market index designed to reflect the stock performance in China; Industry Median Number of Analysts, measured as the natural logarithm of the median number of analysts for firms in the same industry as firm $i$ in year $t$; Industry Leader, an indicator for whether the firm is an industry leader, measured as whether its sales ranked as top $30 \%$ in the industry at the beginning of year $t$. We also include two other variables that are commonly used in the analysis of analyst coverage (e.g. Bushman et al. (2004), Lang and Lundholm (1993), Healy et al. (1999), Francis et al. (1997), Bhushan (1989): $\log (M T B)$, measured as the natural logarithm of market-to-book equity ratio at the beginning of year $t$; and Firm profitability, defined as the ratio of earnings over total equity at the beginning of year $t$. In order to capture the variation in analyst coverage that is exogenous to stock return synchronicity, we also provide statistical tests for relevance (correlated with the endogenous variables) and validity (orthogonal to the residuals or exogenous with the dependent variable).

The first column of Panel B in Table 4 presents the results of the first stage of the 2SLS specification for endogenous analyst coverage. The coefficients for CSI 300, Industry Median Number of Analyst and Industry Leader are all statistically 
significant and positive, indicating that they are important determinants for analyst coverage. $\log (M T B)$ is also negatively associated with analyst coverage, suggesting that value firms attract more analysts. Finally, analyst coverage increases with Firm profitability, suggesting that analysts are prone to follow firms with higher ROE.

The last column in Panel B in Table 4 presents the second-stage results on the effect of ultimate ownership structure and analyst coverage on stock return synchronicity. The coefficients for predicted Log $(1+$ Analyst $)$ and its interaction with ControlOwnership are both positively related to stock return synchronicity and the coefficients are statistically significant at the $1 \%$ level. These findings indicate that it is difficult for analysts to disseminate firm-specific information in China, in particular when they observe firms with a larger separation of control and ownership rights.

We also report a number of diagnostics to show that the instrumental variables (IVs) are valid. Bound et al. (1995) show that when IVs are weakly correlated with the endogenous explanatory variable, even a small correlation between the instruments and the error can seriously bias estimates and lead to a large inconsistency in the IV estimates. They therefore suggest reporting partial F-statistics and $R^{2}$ on the instruments. In our first-stage regression these are 32.174 and 0.372 , respectively. Supported by the analysis in Stock et al. (2002), these results alleviate our concern for potential weaknesses of the instruments. Moreover, the Anderson-Rubin F-statistic rejects the null hypothesis, thus showing that the endogenous regressor is relevant. Since we have multiple instruments for the 
endogenous variable, we also compute a test for instrument exogeneity using over-identifying restrictions. The Sargan test (Hansen test or $J$-test) shows that our IVs jointly pass the exogeneity requirement.

To sum up, the 2SLS analysis corroborates the significant and positive relationship between analyst coverage and stock return synchronicity, especially for firms whose controlling owners have strong incentives to expropriate minority shareholders.

[Table 4 here]

\subsection{Further Robustness Checks}

\subsubsection{Type of Ownership - Family and Non-Family Firms}

Ownership in China differs from most Western countries. In particular, state-controlled firms are still very common in China. A natural question is whether the particular ownership setting in China has an effect on our results. To analyze this, we divide our sample into two groups based on ultimate ownership. If a publicly-traded firm is ultimately controlled by a family, it is categorized as a family firm. Otherwise, we label it as a non-family firm. We then carry out the same empirical analysis as in the two previous sections, with the results presented in Table 5. The results presented in the table are thus from the pooled OLS model, the Fama and MacBeth (1973) specification, and the second stage of the 2SLS estimation, respectively. The results show that the interaction variable (Control - 
Ownership $) * \log (1+$ Analyst $)$ is still positively related with stock return synchronicity, although it is only statistically significant in five of the model specifications. Our main findings thus still hold when we divide the sample based on type of ownership. That is, the expropriating incentives of the ultimate owner, here proxied by (Control Ownership), hinder analysts from disseminating firm-specific information to the market.

[Table 5 here]

\subsubsection{Market Conditions}

Being an emerging market, China's stock market rises and falls rapidly over time. It could be argued that volatile market movements may influence our results. For example, during a bear market, stocks are not very attractive as stock prices fall. Investors can do better by, for example, shifting investments to bonds. However, a bull market increases investors' enthusiasm and the stock market attracts more capital. It is not farfetched to assume that changes in the market trend also may influence analyst behavior. We therefore extend our analysis by taking market conditions into consideration. Figure 4 illustrates the Shanghai Composite Index throughout the sample period. The pattern of the stock market in the figure suggests the existence of a speculative bubble during the sample period. Starting from about 1,200, the Shanghai Composite Index climbed quickly and peaked above 6,100 in October 2007, after which it fell rapidly, bottoming out at 1,800 in November 2008. After then, it 
fluctuated around 2,300 for the rest of the sample period.

[Figure 4 here]

Bry and Boschan (1971) and Hamilton (1989) develop an algorithm to identify bull and bear markets. However, their approach cannot be used in our analysis as we are using annual data. We therefore use a simplified approach in which we construct a rough proxy for bull markets. Here, a bull-market period is defined as years in which the return of tradable value-weighted all A share index exceeds $100 \%$. In our sample, this corresponds to the years 2006, 2007 and 2009, respectively. We label the years 2008, 2010, 2011 and 2012, with the corresponding market return of $-62.6 \%,-6.86 \%$, $-21.35 \%$ and $5.16 \%$, respectively, as non-bull market years.

Regression results for bull market periods and non-bull market periods are presented in Table 6 . In most cases, $\log (1+$ Analyst $)$ is positively related with the stock return synchronicity, but it is only statistically significant in columns (3), (4), and (6). In column (1), the coefficient of $\log (1+$ Analyst) becomes negative, but it is also insignificant. Therefore, there is only weak evidence showing that more analysts disseminate more market-wide information during bull market period. However, the interaction term of (Control - Ownership) and Log(1+Analyst) is still positively and significantly associated with stock return synchronicity in all specifications. This finding suggests that more analyst coverage fail to generate more firm-specific news for firms with separated control and ownership structure.

[Table 6 here] 


\subsubsection{Excluding Observations}

In the above analysis, our sample includes firm observations with zero analyst coverage, which means that the variable $\log (1+$ Analyst $)$ is zero for these observations. It could be argued that firms with no analyst coverage are intrinsically different from others. However, so far, we have implicitly assumed that the only discrepancy between them is the number of analysts who cover them, not whether they are covered or not. To take this into account, we investigate whether our findings change significantly if we exclude firms with zero analyst coverage. The new regression results are presented in columns (1)-(3) of Table 7. Our sample is greatly reduced from 11,913 to 7,637 . However, the main results remains qualitatively the same as the coefficient of (Control - Ownership)*Log $(1+$ Analyst $)$ is still positive and significant at the 1 percent level.

Looking at Synch across years in Panel A in Table 1 again, we find that it is always negative except in 2008 , a year characterized by a significant bear market. Investigating the reason behind this in detail is beyond this study. Here, we only focus on whether it also impacts our main findings. The regression results are presented in columns (4)-(6) in Table 7. Again, our results still hold for samples excluding the year of 2008 .

[Table 7 here] 


\subsubsection{Pyramidal Structure, Analyst Coverage and Stock Return Synchronicity}

We have found that the separation of control and ownership rights inhibits analysts from disseminating firm-specific information. However, voting rights exceeding cash flow rights is a direct consequence of complicated ownership structures. As discussed in Section 3.2.1, pyramidal schemes are often used to separate control and ownership rights in China. To shed further light on this, we analyze how pyramidal structure affects the relation between analyst coverage and stock return synchronicity.

Panel A in Table 8 presents the univariate statistics of stock return synchronicity between firms with and without pyramidal ownership structures. On average, $R^{2}$ (Synch) are $0.356(-0.318)$ and $0.365(-0.292)$ for these two portfolios, respectively. The median value of $R^{2}$ (Synch) corresponds to $0.354(-0.260)$ and $0.361(-0.247)$, respectively. Both the T-test and the Wilcoxon-Mann-Whitney test show that firms with pyramids have significantly larger $R^{2}$ (Synch) than firms without pyramids, indicating an important difference between these two types of firms.

Panel B in Table 8 presents the multivariate regression results of the effect of pyramidal structure and analyst coverage on stock return synchronicity. Results from a pooled OLS model and Fama and MacBeth (1973) estimations are both provided. The coefficient of Pyramids* $\log (1+$ Analyst $)$ is positive and statistically significant at the one percent level, suggesting that more analysts disseminate more market-wide information for pyramidal firms. 
[Table 8 here]

To deal with potential endogeneity, we once more apply a two-stage least square model, for which the regression results are presented in Table 9. Instrumental variables include CSI 300, Industry Median Number of Analysts and Industry Leader. In the first stage of regressions, they are all positively and significantly related with $\log (1+$ Analyst $)$. The Shea partial $R^{2}$ and the $F$-statistic both provide strong support for the joint relevance of our instruments in the first stage. In the second stage, we use predicted $\log (1+$ Analyst $)$ as an independent variable. The results show that $\log (1+$ Analyst $)$ and its interaction with Pyramids are both significantly and positively associated with stock return synchronicity. Thus, our main results still hold. Moreover, the Anderson-Rubin F-statistic indicates the relevance of endogenous regressors. Since we have multiple instruments for the endogenous variable, we also compute the test of instrument exogeneity using over-identifying restrictions. The Hansen J-test indicates that they therefore jointly pass the exogeneity requirement. Summing up, these results provide further support for the argument that pyramidal structures impede firm-specific information dissemination in China.

[Table 9 here]

\section{Alternative Explanation - Noise Trading}

Some studies (Shiller, 1981; West, 1988; Kelly, 2005;Ashbaugh-Skaife, et al., 2006; Pontiff, 2006) suggest that high stock return synchronicity may indicate noise 
trading rather than the efficiency of information dissemination. For example, when more analysts cover a firm, noise-trading is greatly reduced, and as a result stock return synchronicity increases. This alternative explanation is plausible and can explain the positive relationship between analyst coverage and stock return synchronicity, but we argue that it cannot explain our results consistently.

To better understand this alternative story, we first discuss the noise-trading scenario. Noise-trading is especially prominent when no analysts cover a firm because noise traders have difficulty obtaining firm-specific information. In our setting, firms with a larger separation of ownership and control rights are more opaque than firms with a smaller difference between ownership and control rights. Potential noise-trading should therefore be higher if noise-trading is a dominant force for lower stock return synchronicity. This logic indicates that the coefficient of (Control Ownership) should be negative. However, our results do not support this argument. The sign of the coefficient of (Control - Ownership) alleviates the noise-trading concern to a large extent. However, critics may pay attention to the interaction of (Control - Ownership) and Log(1+Analyst). On the one hand, analyst coverage can reduce noise-trading and thus improve stock return synchronicity; one the other hand, a higher degree of separation between ownership and control increases noise-trading, thereby reducing stock return synchronicity. Noise-trading can thus help explain the coefficient of interaction if the former effect dominates the results. We therefore need to examine the relationship between stock return synchronicity and analyst coverage 
in closer detail.

Brennan et al. (1993) argue that firms followed by many analysts adjust their price to common information more quickly, and that the returns on portfolios of firms followed by more analysts as a result lead returns on portfolios of firms followed by fewer analysts. Based on this argument, if firms covered by more analysts have more market-wide information incorporated into their stock prices, then the returns on stocks with high levels of analyst coverage lead returns on stocks with lower level of analyst coverage and not vice versa.

We divide the sample into two subsamples based on (Control - Ownership) and discuss the relationship between stock return synchronicity and analyst coverage. If control rights are larger than cash-flow rights and if this divergence is larger than the median divergence in firms where control and ownership differ, we classify the firm as one with a higher degree of separation between control and ownership rights. The remaining firms are classified as firms with a lower degree of separation between control and ownership rights.

For each year, firms in the same subsample are ranked by their analyst coverage. Based on this ranking, two portfolios are formed, where the first portfolio is composed of firms that are followed by fewer analysts $(F)$ and the second one is composed of firms that are followed by more analysts $(M)$. We then calculate the weekly returns for each portfolio across years for each subsample. Finally, the following vector-autoregressive model is used to examine the lead-lag relation 
between high and low analyst coverage portfolios:

$$
\begin{aligned}
& R_{F, t}=\alpha_{F}+\sum_{k=1}^{K} \beta_{F, t-k} R_{F, t-k}+\sum_{k=1}^{K} \beta_{M, t-k} R_{M, t-k}+\mu_{F, t^{\prime}} \\
& R_{M, t}=\alpha_{M}+\sum_{k=1}^{K} \gamma_{F, t-k} R_{F, t-k}+\sum_{k=1}^{K} \gamma_{M, t-k} R_{M, t-k}+\mu_{M, t^{\prime}}
\end{aligned}
$$

where $R_{F, t}$ and $R_{M, t}$ are weekly returns on the $F$ and $M$ portfolios, respectively, and $K$ is the number of lags. If the sum of coefficients on lagged value of $R_{M, t}$ in (4) is positive, then the past returns of higher analyst coverage portfolio can predict the future returns of lower analyst coverage portfolio. Conversely, if the sum of coefficients on lagged value of $R_{F, t}$ in (5) is positive, then the past returns of lower analyst coverage portfolio can predict the future returns of higher analyst coverage portfolio. If analysts indeed produce market-wide information, then more systematic information will be inferred from firms followed by more analysts. This way, the return of portfolio $M$ will lead that of portfolio $F$ more than vice versa, and thus the sum of the coefficients on lagged value of $R_{M, t}$ in (4) will exceed the sum of the coefficients on lagged values of $R_{F, t}$ in (5).That is,

$$
\sum_{k=1}^{K} \beta_{M, k}>\sum_{k=1}^{K} \gamma_{F, k}
$$

Table 10 presents the sum of coefficients on lagged values of $R_{F, t}$ and $R_{M, t}$. These regressions were fitted with 1, 2 and 3 lags. Consider the estimates of the one-lag regression first. For the subsample of firms with a higher degree of separation 
between ownership and control, $R_{M, t}$ significantly and positively predict the returns on both portfolios $M$ and $F$, while the sums of coefficients on the lagged values of $R_{F, t}$ are typically not different from zero. Therefore, the returns on portfolio $M$ can predict the returns on portfolio $F$, and not vice versa. The Wald statistic is 15.83 , rejecting the null hypothesis that $\sum_{k=1}^{K} \beta_{M, k}>\sum_{k=1}^{K} \gamma_{F, k}$ at the $1 \%$ level. This suggests that firms characterized by more analyst coverage adjust to market-wide information faster. The results of the regressions with two and three lags are similar to the ones of the regression with one lag for the subsample with a higher degree of separation between ownership and control. A similar conclusion can be drawn for firms with a lower degree of separation between ownership and control, although the results for the regression with three lags are much weaker. ${ }^{14}$ Because firm size is closely related to the firm-specific information environment and analyst coverage, we also rank firms according to their market capitalization and then run similar lead-lag relations. To save space, we omit the results, but our main findings do not change substantially (it should be noted that the sample in each VAR model is greatly reduced). Based on the results in this section, we can thus conclude that analysts play an important role in the dissemination of market-wide information, rather than reducing firm-specific noise trading.

[Table 10 here]

\footnotetext{
${ }^{14}$ Fewer sample observations and the longer time lags may be the reason for this non-rejection.
} 


\section{Conclusion}

Despite continued improvements in corporate transparency and disclosure quality, including the adoption of IFRS (International Financial Reporting Standards) and IAAS (International Auditing and Assurance Standards) as well as the strengthening of corporate governance practice, investors in China still question financial reports and generally perceive of financial information as lacking in quality. It is therefore important for academia and regulators to better understand the reasons behind the existence of this environment characterized by poor information disclosure.

Using a unique dataset for the period 2005-2012, this study discusses how ultimate ownership structure affects the information environment of publicly traded firms in China. Concentrated ownership and the associated separation of ultimate control and ownership rights create agency conflicts between controlling shareholders and minority investors. Consequently, controlling owners are reluctant to reveal firm-specific information to the market in order to minimize the cost of their expropriation activities. We test this general conjecture by investigating the effect of ultimate ownership structure and analyst coverage on stock return synchronicity. We find that a larger separation of control and ownership rights significantly and positively increases the response coefficient of stock return synchronicity on analyst coverage. That is, conditioned on the same level of analyst coverage, stock return synchronicity increases when the separation between control and ownership rights increases. A battery of robustness tests confirms these findings and we can also rule 
out noise trading as a potential driver behind the results. A stronger incentive to expropriate funds from minority shareholders as a result of the separation of ownership and control rights contributes to greater corporate opacity, leading analysts to disseminate more market-wide information in China. We believe that the findings in this study have direct policy implications for regulators as they point toward the importance of further improvements in corporate transparency in China. We also believe that our results are beneficial for understanding problems in other emerging economies that are characterized by similar patterns of firm ownership. 


\section{References}

Admati, A., Pfleiderer, P., 1986. A monopolistic market for information. Journal of Economic Theory 39, 400-438.

Ashbaugh-Skaife, H., Gassen, J., LaFond, R., 2005. Does stock price synchronicity represent firm-specific information? International evidence. Massachusetts Institute of Technology, Working paper.

Attig, N., Fong, W., Gadhoum, Y., Lang, L., 2006. Effects of large shareholding on information asymmetry and stock liquidity. Journal of Banking and Finance 30, 2875-2892.

Bae, K., Kang, J., Kim, J., 2002. Tunneling or value-added: Evidence from mergers by Korean business groups. Journal of Finance 57, 2695-2740.

Baek, J., Kang, J., Lee, I., 2006. Business groups and tunneling: evidence from private securities offerings by Korean Chaebols. Journal of Finance 61, 2415-2449.

Berglof, E., Perotti, E.,1994. The governance structure of the Japanese financial keiretsu. Journal of Financial Economics 36, 259-284.

Bertrand, M., Mehta, P., Mullainathan, S., 2002.Ferreting out tunneling: An application to Indian business groups. Quarterly Journal of Economics 117, 121-148.

Bhushan, R., 1989. Firm characteristics and analyst following. Journal of Accounting and Economics 11, 39-65.

Blass, A., Yafeh, Y., Yosha, O.,1998. Corporate governance in an emerging market: The case of Israel. Journal of Applied Corporate Finance 10, 79-89.

Boubaker, S., Mansali, H., Rjiba, H., 2014. Large controlling shareholders and stock price synchronicity. Journal of Banking and Finance 40, 80-96.

Boubakri, N., Ghouma, H., 2010.Control/ownership structure, creditor rights protection, and the cost of debt financing: international evidence. Journal of Banking and Finance 34, 2481-2499.

Bound, J., Jaeger, D., Baker, R., 1995. Problems with instrumental variables estimation when the correlation between the instruments and the endogenous explanatory variable is weak. Journal of the American Statistical Association 90, 443-450.

Brennan, M. J., Jegadeesh, N., Swaminathan, B., 1993. Investment analysis and the adjustment of stock prices to common information. Review of Financial Studies 6, 799-824. 
Bry, G., Boschan, C., 1971. Cyclical analysis of time series: selected procedures and computer programs. National Bureau of Economic Research.

Bushman, R., Piotroski, J., and Smith, A., 2004. What determines corporate transparency? Journal of Accounting and Economics 37, 167-201.

Chan, K., Hameed, A., 2006. Stock price synchronicity and analyst coverage in emerging markets. Journal of Financial Economics 80, 115-147.

Chan, K., Menkveld, A., Yang, Z., 2007. The informativeness of domestic and foreign investors' stock trades: Evidence from the perfectly segmented Chinese market. Journal of Financial Markets 10, 391-415.

Chan, K., Menkveld, A., Yang, Z., 2008. Information asymmetry and asset prices: Evidence from the China foreign share discount. Journal of Finance 63, 159-196.

Chen, G., Firth, M., Xu, L., 2009. Does the type of ownership control matter? Evidence from China's listed companies. Journal of Banking and Finance 33, 171-181.

Chen, J., Ding, R., Hou, W., Johan, S., 2015. Do financial analysts perform a monitoring role in China? Evidence from modified audit opinions. Abacus, forthcoming.

Chen, Q., Goldstein, I., Jiang, W.,2006. Price informativeness and investment sensitivity to stock prices. Review of Financial Studies 18, 289-324.

Chen, S., Matsumoto, D., 2006. Favorable versus unfavorable recommendations: The impact on analyst access to management-provided information. Journal of Accounting Research44, 657-689.

Chernykh, L., 2008. Ultimate ownership and control in Russia. Journal of Financial Economics 88, 169-192.

Cheung, Y., Rau, P., Stouraitis, A., 2006. Tunneling, propping, and expropriation: evidence from connected party transactions in Hong Kong. Journal of Financial Economics 82, 343-386.

Chung, K., Jo., H., 1996. The impact of security analysts' monitoring and marketing functions on the market value of firms. Journal of Financial and Quantitative Analysis 31, 493-512.

Claessens, S., Djankov, S., Fan, J., Lang, L.,2002. Disentangling the incentive and entrenchment effects of large shareholdings. Journal of Finance 57, 2741-2771.

Claessens, S., Djankov, S., Lang, L., 2000. The separation of ownership and control in East Asian corporations. Journal of Financial Economics 58, 81-112.

Clement, M., 1999. Analyst forecast accuracy: Do ability, resources and portfolio complexity matter? Journal of Accounting and Economics 27, 285-304. 
Durnev, A., Morck, R., Yeung, B., Zarowin, P., 2003. Does greater firm-specific return variation mean more or less informed stock pricing? Journal of Accounting Research 41, 797-836.

Durnev, A., Morck, R., Yeung, B., 2004. Does firm-specific information in stock prices guide capital budgeting? Journal of Finance 59, 65-105.

Denis, D., McConnell, J., 2003. International corporate governance. Journal of Financial and Quantitative Analysis 38, 1-36.

Diamond, D., Verrecchia, R., 1981. Information aggregation in a noisy rational expectations economy. Journal of Financial Economics 9, 221-235.

Dyck, A., Zingales, L., 2004. Private benefits of control: An international comparison. Journal of Finance 59, 537-600.

European Corporate Governance Network, 1997. The separation of ownership and control: A survey of 7 European countries preliminary report to the European Commission. Volumes 1-4. Brussels: European Corporate Governance Network.

Faccio, M., Lang, L., 2001. Dividends and expropriation. American Economic Review 91, 54-78.

Faccio, M., Lang, L., 2002. The ultimate ownership of western European corporations. Journal of Financial Economics 65, 365-395.

Fama, E., MacBeth, J., 1973. Risk, return, and equilibrium: empirical tests. Journal of Political Economy 81, 607-636.

Fan, J., Wong, T., 2002. Corporate ownership structure and the informativeness of accounting earnings in East Asia. Journal of Accounting and Economics 33, 401-425.

Feng, X., Johansson, A.C., Zhang, T., 2014. Political participation and entrepreneurial initial public offerings in China. Journal of Comparative Economics 42, 269-285.

Francis,J., Hanna, J., Philbrick, D.,1997. Management communications with securities analysts. Journal of Accounting and Economics 24, 363-394.

Franks, J., Mayer, C., 2001. The ownership and control of German corporations. Review of Financial Studies 14, 943-977.

Gorton, G., Schmid, F., 2000. Universal banking and the performance of German firms. Journal of Financial Economics58, 29-80.

Gu, Z., Li, Z., Yang, G., 2013. Monitors or predators: The influence of institutional investors on sell-side analysts. The Accounting Review 88, 137-169.

Hamilton, J., 1989. A new approach to the economic analysis of nonstationary time series and the business cycle. Econometrica 57, 357-384. 
Haw, I., Hu, B., Hwang, L., Wu, W., 2004. Ultimate ownership, income management, and legal and extra-legal institutions. Journal of Accounting Research 42, 423-462.

Healy, P. M., Wahlen, J.M., 1999. A review of the earnings management literature and its implications for standard setting. Accounting Horizons 13, 365-383.

Holderness, C., Sheehan, D., 1988.The role of majority shareholders in publicly held corporations: An exploratory analysis. Journal of Financial Economics 20, 317-346.

Huang, Z., Li, L., Ma, G., Qian, J., 2014. The political economy of corporate finance: Evidence from 'Re-nationalization' in China. Unpublished manuscript.

Hui, L., 1981.Ownership and control of the one hundred largest corporations in Malaysia. Kuala Lumpur: Oxford University Press.

Jacob, J., Lys, T., Neale, M., 1999.Expertise in forecasting performance of security analysts. Journal of Accounting and Economics 28, 51-82.

Jin, L., Myers, S., 2006. $\mathrm{R}^{2}$ around the world: new theory and tests. Journal of Financial Economics 79, 257-292.

Johnson, S., LaPorta,R., Lopez-de-Silanes,F., Shleifer,A.,2000. Tunneling. American Economic Review Papers and Proceedings 90, 22-27.

Khanna,T.,Yafeh,Y.,2007. Business groups in emerging markets: Paragons or parasites? Journal of Economic Literature 45, 331-372.

Kelly, P., 2005. Information efficiency and firm-specific return variation. University of South Florida, Working paper.

Lang, M., Lundholm, R., 1996. Corporate disclosure policy and analyst behavior. The Accounting Review 71, 467-492.

La Porta, R., Lopez-de-Silanes, F., Shleifer, A., Vishny, R.,1997.Legal determinants of external finance. Journal of Finance 52, 1131-1150.

La Porta, R., Lopez-de-Silanes, F., Shleifer, A., Vishny, R., 1998.Law and finance. Journal of Political Economics 106, 1113-1155.

La Porta, R., Lopez-de-Silanes, F., Shleifer, A.,Vishny, R.,1999. Corporate ownership around the world. Journal of Finance 54, 471-517.

La Porta, R., Lopez-de-Silanes, F., Shleifer, A., Vishny, R., 2000. Agency problems and dividend policies around the world. Journal of Finance 55,1-33.

La Porta, R., Lopez-de-Silanes, F., Shleifer, A., Vishny, R.,2002. Investor protection and corporate valuation. Journal of Finance 57, 1147-1170. 
Leuz, C., Nanda, D., Wysocki, P., 2003. Earnings management and investor protection: An international comparison. Journal of Financial Economics 69, 505-527.

Li, H., Meng, L., Wang, Q., Zhou, L., 2008. Political connections, financing and firm performance: Evidence from Chinese private firms. Journal of Development Economics 87, 283-299.

Lin, C., Liu, P., Xuan, Y., 2013. The client is king: Do mutual fund relationships bias analyst recommendations? Journal of Accounting Research 51, 165-200.

Lins, K., 2003. Equity ownership and firm value in emerging markets. Journal of Financial and Quantitative Analysis 38, 159-184.

Masulis, R., Wang, C., Xie, F., 2009.Agency problems at dual-class companies. Journal of Finance 64, 1697-1727.

Morck, R., Shleifer, A., Vishny, R.,1988. Management ownership and market valuation: An empirical analysis. Journal of Financial Economics 20, 293-315.

Morck, R., Yeung, B., Yu, W., 2000. The information content of stock markets: Why do emerging markets have synchronous stock price movements? Journal of Financial Economics 59, 215-260.

Nenova, T., 2003. The value of corporate voting rights and control: A cross-country analysis. Journal of Financial Economics68, 325-352.

Newey, W., West, K., 1987. A simple, positive semi-definite, heteroskedasticity and autocorrelation consistent covariance matrix. Econometrica 55, 703-708.

O'Brien, P., Bhushan, R., 1990. Analyst following and institutional ownership. Journal of Accounting Research 28, 55-76.

Petersen, M.,2009. Estimating standard errors in finance panel data sets: Comparingapproaches. Review of Financial Studies 22, 435-480.

Piotroski, J., Roulstone, D., 2004. The influence of analysts, institutional investors, and insiders on the incorporation of market, industry, and firm-specific information into stock prices. Accounting Review 79, 1119-1151.

Pistor, K., Xu, C.,2005. Governing stock markets in transition economies: Lessons from China. American Law and Economics Review 7, 184-210.

Pontiff, J., 2006.Costly arbitrage and the myth of idiosyncratic risk. Journal of Accounting and Economics 42, 35-52.

Qu, H., Liu, W., Sheng, T., 2014. Twisted analysts research: from digging information to digging insiders. Shanghai Securities News, July 8. (In Chinese) 
Ramnath, S., 2002. Investor and analyst reactions to earnings announcements of related firms: An empirical analysis. Journal of Accounting Research 40, 1351-1376.

Roll, R., 1988. R-squared. Journal of Finance 43, 541-566.

Shiller, R., 1981. Do stock prices move too much to be justified by subsequent changes in dividends? American Economic Review 71, 421-436.

Shleifer, A., Vishny, R., 1997. A survey of corporate governance. Journal of Finance $52,737-783$.

Stock, J.H., Wright, J.H., Yogo, M., 2002. A survey of weak instruments and weak identification in generalized method of moments. Journal of Business and Economic Statistics 20, 518-529.

Sun, W., Peng, X., 2010. Plagiarism in research reports reflects internal auditing loopholes of brokerage firms. Securities Times, July 27. (In Chinese)

Thompson, S., 2011. Simple formulas for standard errors that cluster by both firm and time. Journal of Financial Economics 99, 1-10.

Volpin, P., 2002. Governance with poor investor protection: Evidence from top executive turnover in Italy. Journal of Financial Economics64, 61-90.

Wei, K., Zhang, Y., 2008. Ownership structure, cash flow, and capital investment: Evidence from East Asian economies before the financial crisis. Journal of Corporate Finance 14, 118-132.

West K., 1988. Dividend innovations and stock price volatility. Econometrica 56, $37-61$.

Wu, T., Pan, X., 2011. The independence of sell-side analysts call into question. Securities Daily, December 14. (In Chinese)

Wurgler, J., 2000. Financial markets and the allocation of capital. Journal of Financial Economics 58, 187-214.

Zhang, L., 2011. The interests chain underlying research reports issued by brokerage firms. Beijing Business Today, March 17. (In Chinese) 
Table 1. The Sample

Panel A: Distribution of Sample by Year

This panel presents the distribution of our sample by year during 2005-2012. Synch is a commonly used stock return synchronicity measure, calculated as $\log \left(R^{2} /\left(1-R^{2}\right)\right) \cdot R^{2}$ is from regressions of the market model of return of the firm against the stock market index and industry index using weekly data.

\begin{tabular}{|c|c|c|c|c|c|c|c|}
\hline \multirow[b]{2}{*}{ Year } & \multirow[b]{2}{*}{ Number } & \multicolumn{3}{|c|}{ Synch } & \multicolumn{3}{|c|}{$R^{2}$} \\
\hline & & Mean & Median & STD & Mean & Median & STD \\
\hline 2005 & 1165 & -0.273 & -0.228 & 0.312 & 0.365 & 0.372 & 0.133 \\
\hline 2006 & 1205 & -0.649 & -0.548 & 0.519 & 0.230 & 0.221 & 0.137 \\
\hline 2007 & 1268 & -0.536 & -0.479 & 0.324 & 0.248 & 0.249 & 0.105 \\
\hline 2008 & 1416 & 0.014 & 0.040 & 0.288 & 0.511 & 0.523 & 0.143 \\
\hline 2009 & 1473 & -0.210 & -0.170 & 0.335 & 0.398 & 0.403 & 0.151 \\
\hline 2010 & 1635 & -0.409 & -0.371 & 0.426 & 0.313 & 0.299 & 0.162 \\
\hline 2011 & 1781 & -0.209 & -0.184 & 0.304 & 0.395 & 0.396 & 0.144 \\
\hline 2012 & 1970 & -0.205 & -0.162 & 0.360 & 0.403 & 0.408 & 0.160 \\
\hline Total & 11913 & -0.295 & -0.249 & 0.409 & 0.364 & 0.360 & 0.166 \\
\hline
\end{tabular}


Table 1. The Sample (contd.)

Panel B: Distribution of Sample by Industry

This panel presents the distribution of the sample by industry during 2005-2012. Industry is classified according to the Guidelines for the Industry Classification of Listed Companies by CSRC (2001 Revision).

\begin{tabular}{|c|c|c|c|c|c|c|c|}
\hline \multirow[b]{2}{*}{ Industry } & \multirow[b]{2}{*}{ Number } & \multicolumn{3}{|c|}{ Synch } & \multicolumn{3}{|c|}{$R^{2}$} \\
\hline & & Mean & Median & STD & Mean & Median & STD \\
\hline Agriculture, Forestry, farming \& fishery & 224 & -0.351 & -0.303 & 0.316 & 0.329 & 0.333 & 0.134 \\
\hline Mining & 327 & -0.159 & -0.112 & 0.377 & 0.427 & 0.436 & 0.171 \\
\hline Food \& Beverage & 559 & -0.386 & -0.337 & 0.376 & 0.319 & 0.315 & 0.150 \\
\hline Textiles \& Apparel & 448 & -0.318 & -0.272 & 0.404 & 0.353 & 0.348 & 0.166 \\
\hline Timber \& Furnishings & 53 & -0.282 & -0.210 & 0.361 & 0.365 & 0.382 & 0.170 \\
\hline Paper \& Printing & 199 & -0.232 & -0.176 & 0.370 & 0.391 & 0.400 & 0.161 \\
\hline Petrochemicals & 1270 & -0.288 & -0.228 & 0.417 & 0.367 & 0.372 & 0.161 \\
\hline Electronics & 539 & -0.315 & -0.279 & 0.406 & 0.355 & 0.345 & 0.166 \\
\hline Metals \& Non-metals & 982 & -0.210 & -0.181 & 0.396 & 0.403 & 0.397 & 0.172 \\
\hline Machinery & 1818 & -0.297 & -0.264 & 0.381 & 0.360 & 0.353 & 0.160 \\
\hline Pharmaceuticals & 786 & -0.412 & -0.349 & 0.410 & 0.312 & 0.309 & 0.154 \\
\hline Other manufacturing & 105 & -0.358 & -0.372 & 0.341 & 0.327 & 0.298 & 0.145 \\
\hline Utilities & 495 & -0.243 & -0.206 & 0.367 & 0.384 & 0.384 & 0.163 \\
\hline Construction & 249 & -0.212 & -0.169 & 0.355 & 0.399 & 0.404 & 0.161 \\
\hline Transportation & 477 & -0.165 & -0.135 & 0.395 & 0.424 & 0.423 & 0.177 \\
\hline Information Technology & 651 & -0.356 & -0.289 & 0.419 & 0.336 & 0.339 & 0.154 \\
\hline
\end{tabular}


Whole sale \& Retail Trade

Finance

Real estate

Social Services

Communication \& Culture

Conglomerate

Total
818

110

908

389

134

372

11913

$\begin{array}{lll}-0.331 & -0.285 & 0.446 \\ -0.031 & 0.005 & 0.333 \\ -0.333 & -0.266 & 0.475 \\ -0.319 & -0.260 & 0.412 \\ -0.386 & -0.321 & 0.421 \\ -0.232 & -0.187 & 0.381 \\ -0.295 & -0.249 & 0.409\end{array}$

0.342

0.503

0.351

0.355

0.323

0.394

0.360
0.168

0.162

0.177

0.165

0.155

0.166

0.166 
Table 2.Summary Statistics

Panel A: Stock Return Synchronicity and Analyst Following

This panel presents the summary statistics for the sample portfolios with Zero, Low, Medium, and High analyst following. Mean is the average across all firms and years, and the corresponding median is given in parentheses. All continuous variables are winsorized at the top and bottom $1 \%$. The last column (4)-(1) reports $T$-test (Wilcoxon-Mann-Whitney test) for the difference between High and Zero analyst following portfolios. ${ }^{* *},{ }^{* *}$ and $*$ denote significance at $1 \%, 5 \%$, and $10 \%$, respectively.

\begin{tabular}{llllll}
\hline & \multicolumn{3}{l}{ Analyst Following } & & \\
\cline { 2 - 4 } \cline { 5 - 6 } & $(1)$ & $(2)$ & $(3)$ & $(4)$ & \\
\hline Analyst & Zero & Low & Medium & High & T(WMW) test \\
Following & 0 & 1.733 & 7.969 & 35.291 & $-166.45^{* * *}$ \\
$R^{2}$ & $(0)$ & $(2)$ & $(7)$ & $(29)$ & $\left(80.51^{* * *}\right)$ \\
& 0.346 & 0.370 & 0.376 & 0.386 & $-7.40^{* * *}$ \\
Synch & $(0.340)$ & $(0.368)$ & $(0.374)$ & $(0.388)$ & $\left(6.84^{* * *}\right)$ \\
& -0.339 & -0.278 & -0.261 & -0.247 & -7.75 \\
$\mathrm{~N}$ & $(-0.287)$ & $(-0.241)$ & $(-0.223)$ & $(-0.213)$ & $\left(6.84^{* * *}\right)$ \\
\hline
\end{tabular}


Table 2.Summary Statistics (contd.)

Panel B: Stock Return Synchronicity and Control - Ownership

This panel presents the summary statistics for the sample portfolios with Zero, Low, Medium, and High (Control - Ownership). Mean is the average across all firms and years, and the corresponding median is given in parentheses. All continuous variables are winsorized at the top and bottom 1\%. The last column (4)-(1) reports the T-test (Wilcoxon-Mann-Whitney test) of the difference between High and Zero (Control -Ownership) portfolios. $* * * * *$ and $*$ denote significance at $1 \%, 5 \%$, and $10 \%$, respectively.

\begin{tabular}{|c|c|c|c|c|c|}
\hline & Control - & wnership & & & \\
\hline & (1) & (2) & (3) & (4) & (4)-(1) \\
\hline & Zero & Low & $\begin{array}{l}\text { Mediu } \\
\mathrm{m}\end{array}$ & High & T (WMW) Test \\
\hline Control - & 0 & 0.038 & 0.122 & 0.218 & $124.71 * * *$ \\
\hline Ownership & $(0)$ & $(0.039)$ & $(0.121)$ & $(0.206)$ & $(88.12 * * *)$ \\
\hline$R^{2}$ & 0.348 & 0.356 & 0.384 & 0.402 & $6.03 * * *$ \\
\hline & $(0.343)$ & $(0.349)$ & $(0.355)$ & $(0.370)$ & $(5.55 * * *)$ \\
\hline Synch & -0.326 & -0.302 & -0.265 & -0.215 & $5.80 * * *$ \\
\hline & $(-0.281)$ & $(-0.269)$ & $(-0.257$ & $(-0.229)$ & $(5.55 * * *)$ \\
\hline & & & ） & & \\
\hline $\mathrm{N}$ & 6083 & 2028 & 1928 & 1874 & \\
\hline
\end{tabular}


Table 3. Separation of Ownership and Control, Analyst Following and Stock Return Synchronicity

This table presents the results of the effect of the separation of ownership and control, analyst following, and their interaction on stock synchronicity. The sample period is from 2005 to 2012. The dependent variable is Synch, a commonly used stock return synchronicity measure, calculated as $\log \left(R^{2} /\left(1-R^{2}\right)\right) . R^{2}$ is from regressions of the market model of return of the firm against the stock market index and industry index using weekly data. $\log (1+$ Analyst $)$ is the natural logarithm of one plus the number of analysts that cover firm $i$ at year t.(Control - Ownership) is the difference between the ultimate owner's control rights and ownership. Size is the natural logarithm of market capitalization of firm $i$ at the beginning of year t. Leverage is defined as the book value of all liabilities scaled by total assets, again measured at the beginning of the year $t$. Segments is the number of segments, including only those which sales that exceed $30 \%$ of firm i's total sales at the beginning of year $t$. Ownership is defined as the cash holding rights of the ultimate owners. Volume is the natural logarithm of trading volume of firm $i$ at year $t$. Volatility is the standard deviation of the stock return of firm $i$ at year $t$. Illiquidity is defined as the average ratio of daily absolute returns to the daily trading volume at year $t$, multiplied by $10^{9} \%$ INST is the ratio of mutual funds' holdings, measured as the aggregate number of shares held by mutual funds, scaled by outstanding shares of firm $I$ in year $t$. Investibility is the investibility measure of firm $i$ at year $t$. HHI (Herfindahl-Hirschman Index) is an indicator of competition, estimated by using all listed firms' sales from the same industry at the beginning of year $t$. Synchronous fundamentals is defined as the Spearman correlation between the firm's ROA and its industrial average ROA over the past ten quarters. Model (1) presents the results from the OLS in which year and industry dummies are included but not reported. $t$-statistics are given in parentheses and computed using heteroskedasticity-robust standard errors clustered by firm and year (Petersen, 2009; Thompson, 2011).Column (2) presents Fama and MacBeth(1973) panel results. Industry dummies are included but not reported and $t$-statistics are computed using heteroskedasticity-robust standard errors clustered by industry. All continuous variables are winsorized at the top and bottom $1 \%{ }^{* * *}, * *$, and $*$ denote significance at the $1 \%, 5 \%$, and $10 \%$ level, respectively.

\begin{tabular}{lll}
\hline & $(1)$ & $(2)$ \\
& OLS & Fama and MacBeth(1973) \\
\hline Log(1+Analyst) & $0.008^{* *}$ & $0.009^{*}$ \\
& $(2.11)$ & $(1.82)$ \\
(Control - Ownership) & 0.116 & 0.122 \\
& $(1.10)$ & $(0.66)$ \\
(Control - Ownership)* $^{*}$ & $0.013^{* * *}$ & $0.010^{* *}$ \\
Log(1+Analyst) & $(2.94)$ & $(2.03)$ \\
Size & $-0.035^{* * *}$ & $-0.077^{* * *}$
\end{tabular}




\begin{tabular}{|c|c|c|}
\hline & $(-5.00)$ & $(-4.02)$ \\
\hline \multirow[t]{2}{*}{ Leverage } & $-0.083 * * *$ & $-0.092 * * *$ \\
\hline & $(-6.05)$ & $(-2.74)$ \\
\hline \multirow[t]{2}{*}{ Segments } & 0.008 & 0.009 \\
\hline & $(0.90)$ & $(0.38)$ \\
\hline \multirow[t]{2}{*}{ Ownership } & 0.101 & 0.102 \\
\hline & $(0.32)$ & $(0.91)$ \\
\hline \multirow[t]{2}{*}{ Volume } & $0.084 * * *$ & $0.110 * * *$ \\
\hline & $(12.67)$ & $(5.74)$ \\
\hline \multirow[t]{2}{*}{ Volatility } & $-6.333 * * *$ & $-6.631 * * *$ \\
\hline & $(-26.29)$ & $(-9.96)$ \\
\hline \multirow[t]{2}{*}{ Illiquidity } & $-1.872 * * *$ & $-3.571 * * *$ \\
\hline & $(-10.68)$ & $(-4.05)$ \\
\hline \multirow[t]{2}{*}{$\%$ INST } & $-0.606^{* * *}$ & $-0.557 * * *$ \\
\hline & $(-18.76)$ & $(-6.21)$ \\
\hline \multirow[t]{2}{*}{ Investibility } & -0.008 & $-0.125 * *$ \\
\hline & $(-0.53)$ & $(-2.08)$ \\
\hline \multirow[t]{2}{*}{ HHI } & -0.116 & -0.271 \\
\hline & $(-0.77)$ & $(-0.47)$ \\
\hline \multirow[t]{2}{*}{ Synchronous fundamentals } & -0.009 & -0.012 \\
\hline & $(-1.19)$ & $(-0.42)$ \\
\hline \multirow[t]{2}{*}{ Intercept } & $-0.839 * * *$ & $-0.594 * * *$ \\
\hline & $(-6.45)$ & $(-4.15)$ \\
\hline Year Dummy & Yes & No \\
\hline Industry Dummy & Yes & Yes \\
\hline $\mathrm{N}$ & 11913 & 11913 \\
\hline Adjusted $R^{2}$ & 0.332 & 0.229 \\
\hline
\end{tabular}


Table 4. The Separation of Ownership and Control, Analyst Coverage and Stock Return Synchronicity: 2SLS

Panel A: Summary Statistics

This panel presents the summary statistics of instruments and other variables that affect analyst coverage. The instruments for the endogenous variables include CSI 300 , an indicator for whether the firm is a constituent stock of CSI 300, a market index designed to reflect the stock performance in China; Industry Median Number of Analysts, measured as the natural logarithm of the median number of analysts for firms in the same industry as firm $I$ in year $t$; Industry Leader, an indicator for whether the firm is an industry leader, measured as whether its sales ranked as top 30\% in its industry at the beginning of year $t ; \log (M T B)$, measured as the natural logarithm of market-to-book equity ratio at the beginning of year $t$; Firm profitability, defined as the ratio of earnings over total equities at the beginning of year $t$. All variables are winsorized at the top and bottom $1 \%$.

\begin{tabular}{llllll}
\hline & Mean & Median & STD & Min & Max \\
\hline $\begin{array}{l}\text { CSI 300 } \\
\begin{array}{l}\text { Industry Median } \\
\text { Number }\end{array}\end{array}$ & 0.190 & 0.000 & 0.392 & 0.000 & 1.000 \\
$\begin{array}{l}\text { of Analyst } \\
\text { Industry Leader }\end{array}$ & 1.242 & 1.099 & 0.821 & 0.000 & 3.784 \\
Log(MTB) & 0.325 & 0.000 & 0.468 & 0.000 & 1.000 \\
Firm profitability & 1.013 & 0.955 & 0.708 & -0.381 & 3.061 \\
\hline
\end{tabular}


Table 4. The Separation of Ownership and Control, Analyst Coverage and Stock Return Synchronicity: 2SLS (contd.)

\section{Panel B: Two Stage Least Square Regression}

This panel reports the 2SLS results of the separation of ownership and control, analyst following and its interaction on stock return synchronicity. First, a Tobit model is used to consider the endogenous determinants of analyst following. The predicted analyst coverage is then included as an independent variable in the second-stage regression to study its effect and its interaction with pyramids on stock return synchronicity. The sample period is from 2005 to 2012. In the first stage, the dependent variable is $\log (1+$ Analyst $)$, defined as the natural logarithm of one plus the number of analysts coverage for firm $i$ at year $t$. In the second stage, the dependent variable is Synch, a commonly used stock return synchronicity measure, calculated as $\log \left(R^{2} /\left(1-R^{2}\right)\right) \cdot R^{2}$ is from regressions of the market model of return of the firm against the stock market index and industry index using weekly data. Statistics from tests for relevance and validity of instruments are reported in the bottom panel. All variables are winsorized at the top and bottom 1\%. All specifications contain year and industry dummies. Values of the $t$-statistics are in parentheses and are computed using the heteroskedasticity-robust standard errors clustered by firm and year (Petersen, 2009; Thompson, 2011). $* * *, * *$, and * denote significance at the $1 \%, 5 \%$, and $10 \%$ level, respectively.

\begin{tabular}{|c|c|c|}
\hline & First Stage & Second Stage \\
\hline Dependent Variables & $\log (1+$ Analyst $)$ & Synch \\
\hline Predicted $\log (1+$ Analyst $)$ & & $\begin{array}{l}0.194 * * * \\
(10.71)\end{array}$ \\
\hline (Control - Ownership) & $\begin{array}{l}-0.378 * * * \\
(-3.45)\end{array}$ & $\begin{array}{l}0.047 \\
(0.68)\end{array}$ \\
\hline (Control - Ownership)* & & $0.025 * * *$ \\
\hline Predicted Log(1+Analyst) & & $(4.95)$ \\
\hline CSI 300 & $\begin{array}{l}-0.091 * * * \\
(-3.13)\end{array}$ & \\
\hline Industry Median Number & $0.316 * * *$ & \\
\hline of Analyst & $(13.81)$ & \\
\hline Industry Leader & $\begin{array}{l}0.059 * * * \\
(2.59)\end{array}$ & \\
\hline $\log (\mathrm{MTB})$ & $\begin{array}{l}-0.167 * * * \\
(-10.42)\end{array}$ & \\
\hline Firm profitability & $\begin{array}{l}0.561 * * * \\
(10.85)\end{array}$ & \\
\hline Size & $\begin{array}{l}0.567 * * * \\
(28.79)\end{array}$ & $\begin{array}{l}-0.142 * * * \\
(-11.54)\end{array}$ \\
\hline
\end{tabular}




\begin{tabular}{|c|c|c|}
\hline Leverage & $\begin{array}{l}-0.145^{* * *} \\
(-3.10)\end{array}$ & $\begin{array}{l}0.023 \\
(1.33)\end{array}$ \\
\hline Segments & $\begin{array}{l}-0.111 * * * \\
(-5.10)\end{array}$ & $\begin{array}{l}0.029 * * * \\
(3.35)\end{array}$ \\
\hline Ownership & $\begin{array}{l}0.140 * * \\
(2.36)\end{array}$ & $\begin{array}{l}0.049 * * \\
(2.09)\end{array}$ \\
\hline Volume & $\begin{array}{l}0.150 * * * \\
(8.74)\end{array}$ & $\begin{array}{l}0.051 * * * \\
(7.07)\end{array}$ \\
\hline Volatility & $\begin{array}{l}-7.485^{* * *} \\
(-11.52)\end{array}$ & $\begin{array}{l}-4.468 * * * \\
(-15.13)\end{array}$ \\
\hline Illiquidity & $\begin{array}{l}5.419 * * * \\
(11.75)\end{array}$ & $\begin{array}{l}-2.799 * * * \\
(-14.02)\end{array}$ \\
\hline$\%$ INST & $\begin{array}{l}3.901 \\
(50.73)\end{array}$ & $\begin{array}{l}-1.312 * * * \\
(-17.55)\end{array}$ \\
\hline Investibility & $\begin{array}{l}0.045 \\
(1.10)\end{array}$ & $\begin{array}{l}-0.020 \\
(-1.26)\end{array}$ \\
\hline HHI & $\begin{array}{l}0.054 \\
(0.14)\end{array}$ & $\begin{array}{l}-0.072 \\
(-0.48)\end{array}$ \\
\hline Synchronous fundamentals & $\begin{array}{l}0.052 * * * \\
(2.68)\end{array}$ & $\begin{array}{l}-0.020 * * * \\
(-2.58)\end{array}$ \\
\hline Intercept & $\begin{array}{l}-14.380 * * * \\
(-37.80)\end{array}$ & $\begin{array}{l}1.937 * * * \\
(6.68)\end{array}$ \\
\hline Year Dummy & Yes & Yes \\
\hline Industry Dummy & Yes & Yes \\
\hline $\mathrm{N}$ & 11913 & 11913 \\
\hline Adjusted $R^{2}$ & 0.623 & 0.334 \\
\hline \multicolumn{3}{|c|}{ Tests of Exogeneity, Relevance and Validity of Instruments } \\
\hline Shea Partial $R^{2}:$ First Stage & 0.372 & \\
\hline F-statistic: First Stage & $32.174 * * *$ & \\
\hline Anderson-Rubin F-statistic & & $23.985 * * *$ \\
\hline Hansen $J$-statistic & & 0.650 \\
\hline
\end{tabular}


Table 5. Type of Ownership - Family and Non-Family Firms

This table presents the regression results of ultimate ownership, analyst coverage and its interaction on stock return synchronicity, for the subsamples with family and non-family firms. All variables are defined in Appendix 1.Column (1) presents the OLS results. Column (2) presents the Fama and MacBeth (1973) panel results. Column (3) presents the 2SLS second-stage result where the predicted analyst coverage value is included as independent variable. Year/Industry dummies are included but not reported, and $t$-statistics are given in parentheses and computed using heteroskedasticity-robust standard errors clustered by firm/industry and year where appropriate (Petersen, 2009; Thompson, 2011). All continuous variables are winsorized at the top and bottom $1 \%{ }^{* * *}, * *$, and $*$ denote significance at the $1 \%, 5 \%$, and $10 \%$ level, respectively.

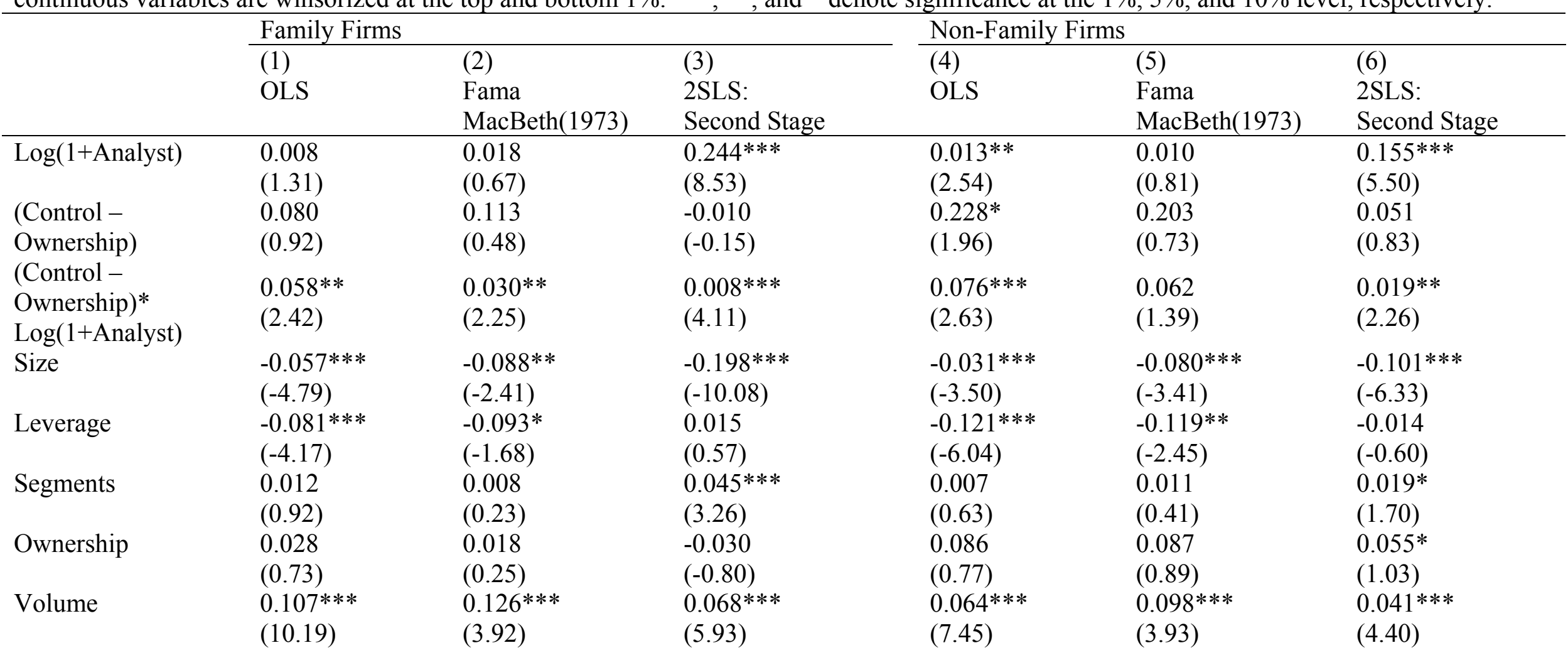




\begin{tabular}{|c|c|c|c|c|c|c|}
\hline Volatility & $\begin{array}{l}-7.841 * * * \\
(-20.62)\end{array}$ & $\begin{array}{l}-7.709 * * * \\
(-7.32)\end{array}$ & $\begin{array}{l}-5.624 * * * \\
(-12.21)\end{array}$ & $\begin{array}{l}-5.085 * * * \\
(-16.23)\end{array}$ & $\begin{array}{l}-5.807 * * * \\
(-6.42)\end{array}$ & $\begin{array}{l}-3.730 * * * \\
(-9.66)\end{array}$ \\
\hline Illiquidity & $\begin{array}{l}-1.737 * * * \\
(-6.63)\end{array}$ & $\begin{array}{l}-2.632 * * \\
(-2.09)\end{array}$ & $\begin{array}{l}-2.897 * * * \\
(-9.63)\end{array}$ & $\begin{array}{l}-1.937 * * * \\
(-7.73)\end{array}$ & $\begin{array}{l}-4.934 * * * \\
(-3.05)\end{array}$ & $\begin{array}{l}-2.533 * * * \\
(-917)\end{array}$ \\
\hline$\%$ INST & $\begin{array}{l}-0.677 * * * \\
(-13.03)\end{array}$ & $\begin{array}{l}-0.610^{* * *} \\
(-4.22)\end{array}$ & $\begin{array}{l}-1.568^{* * * *} \\
(-13.49)\end{array}$ & $\begin{array}{l}-0.547 * * * \\
(-13.22)\end{array}$ & $\begin{array}{l}-0.544 * * * \\
(-4.43)\end{array}$ & $\begin{array}{l}-1.046^{* * *} \\
(-10.56)\end{array}$ \\
\hline Investibility & $\begin{array}{l}-0.052 * * \\
(-2.08)\end{array}$ & $\begin{array}{l}-0.099 \\
(-1.22)\end{array}$ & $\begin{array}{l}-0.062 * * \\
(-2.43)\end{array}$ & $\begin{array}{l}-0.034 \\
(-1.53)\end{array}$ & $\begin{array}{l}-0.176^{* *} \\
(-2.23)\end{array}$ & $\begin{array}{l}-0.037^{*} \\
(-1.65)\end{array}$ \\
\hline HHI & $\begin{array}{l}-0.269 \\
(-1.22)\end{array}$ & $\begin{array}{l}-2.390 \\
(-0.90)\end{array}$ & $\begin{array}{l}-0.267 \\
(-1.21)\end{array}$ & $\begin{array}{l}0.102 \\
(0.50)\end{array}$ & $\begin{array}{l}1.662 \\
(0.23)\end{array}$ & $\begin{array}{l}0.137 \\
(0.67)\end{array}$ \\
\hline $\begin{array}{l}\text { Synchronous } \\
\text { fundamentals }\end{array}$ & $\begin{array}{l}0.021 * * \\
(1.88)\end{array}$ & $\begin{array}{l}0.027 \\
(0.69)\end{array}$ & $\begin{array}{l}-0.038^{* * *} \\
(-3.33)\end{array}$ & $\begin{array}{l}0.002 \\
(0.20)\end{array}$ & $\begin{array}{l}0.003 \\
(0.15)\end{array}$ & $\begin{array}{l}0.002 \\
(0.18)\end{array}$ \\
\hline Intercept & $\begin{array}{l}-0.702^{* * *} \\
(-3.12)\end{array}$ & $\begin{array}{l}-0.519^{* * * *} \\
(-3.53)\end{array}$ & $\begin{array}{l}2.835^{* * *} \\
(6.18)\end{array}$ & $\begin{array}{l}-0.577 * * * \\
(-3.41)\end{array}$ & $\begin{array}{l}-0.371 \\
(-0.49)\end{array}$ & $\begin{array}{l}1.261^{* * *} \\
(3.34)\end{array}$ \\
\hline Year Dummy & Yes & No & Yes & Yes & No & Yes \\
\hline Industry Dummy & Yes & Yes & Yes & Yes & Yes & Yes \\
\hline $\mathrm{N}$ & 5363 & 5363 & 5363 & 6550 & 6550 & 6550 \\
\hline Adjusted $R^{2}$ & 0.331 & 0.216 & 0.335 & 0.335 & 0.238 & 0.335 \\
\hline
\end{tabular}




\section{Table 6.Bull and Non-Bull Markets}

This panel presents the regression results of ultimate ownership, analyst coverage and its interaction on stock return synchronicity, respectively for subsamples characterize by bull and non-bull markets, respectively. A bull market period is defined as a year in which the return of tradable-weighted all A share index exceeds 100\%. All variables are defined in Appendix 1.Column (1) presents the OLS results. Column (2) presents the Fama and MacBeth (1973) panel results. Column (3) presents the 2SLS second stage result with the predicted analyst coverage value as an independent variable. Year/Industry dummies are included but not reported, and $t$-statistics are given in parentheses and computed using heteroskedasticity-robust standard errors clustered by firm/industry and year where appropriate (Petersen, 2009; Thompson, 2011). All continuous variables are winsorized at the top and bottom $1 \%$. ***, **, and $*$ denote significance at the $1 \%, 5 \%$, and $10 \%$ level, respectively

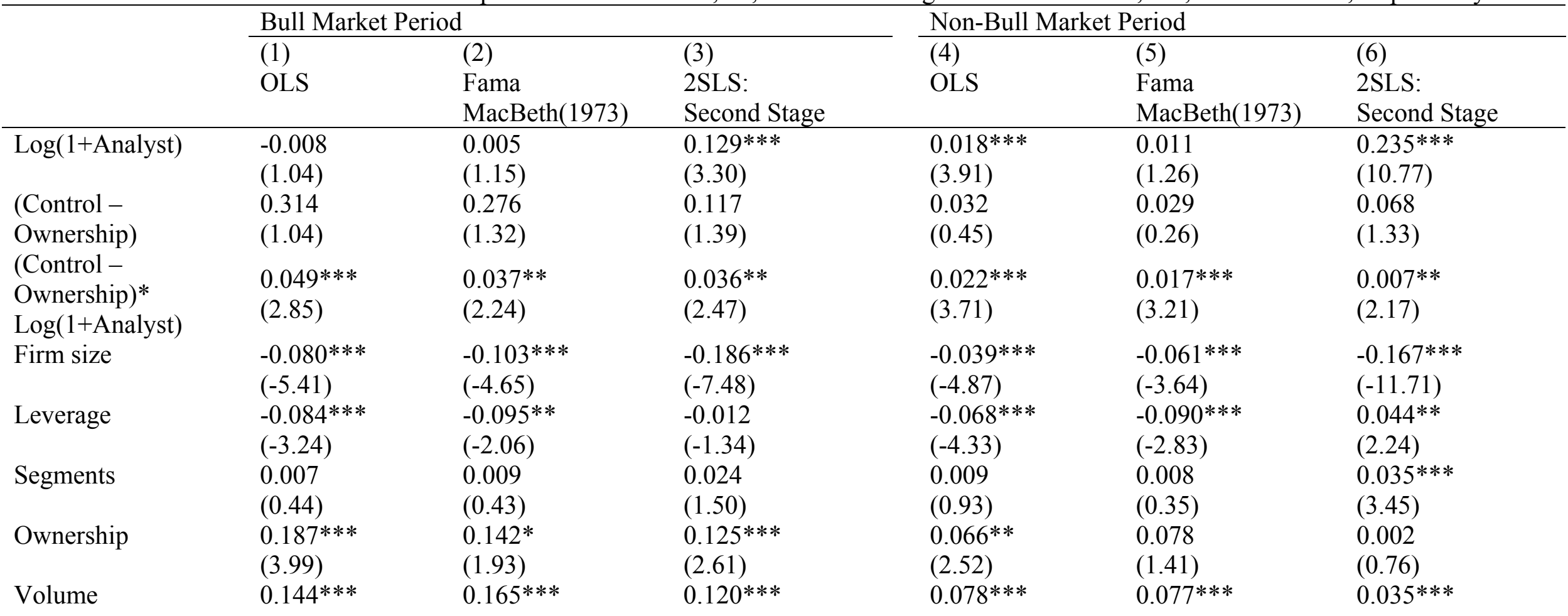




\begin{tabular}{|c|c|c|c|c|c|c|}
\hline & $(9.55)$ & $(6.98)$ & $(7.41)$ & (10.42) & (4.99) & $(4.32)$ \\
\hline \multirow[t]{2}{*}{ Volatility } & $-4.567 * * *$ & $-5.141 * * *$ & $-2.970 * * *$ & $-8.078 * * *$ & $-7.525 * * *$ & $-5.643 * * *$ \\
\hline & $(-11.95)$ & $(-8.08)$ & $(-5.86)$ & $(-25.46)$ & $(-11.09)$ & $(-15.02)$ \\
\hline \multirow[t]{2}{*}{ Illiquidity } & $-3.126 * * *$ & $-3.065 * * *$ & $-4.007 * * *$ & $-1.062 * * *$ & $-3.875 * * *$ & $-2.164 * * *$ \\
\hline & $(-8.20)$ & $(-3.92)$ & $(-9.34)$ & $(-5.47)$ & $(-4.14)$ & $(-9.79)$ \\
\hline \multirow[t]{2}{*}{$\%$ INST } & $-0.257 * * *$ & $-0.269 * * *$ & $-0.911 * * *$ & $-0.804 * * *$ & $-0.731 * * *$ & $-1.647 * * *$ \\
\hline & $(-4.46)$ & $(-2.81)$ & $(-6.12)$ & $(-20.43)$ & $(-8.25)$ & $(-18.78)$ \\
\hline \multirow[t]{2}{*}{ Investibility } & -0.037 & -0.147 & $-0.062 *$ & -0.020 & $-0.111 * *$ & $-0.033^{*}$ \\
\hline & $(-1.03)$ & $(-1.62)$ & $(-1.70)$ & $(-1.15)$ & $(-2.34)$ & $(-1.86)$ \\
\hline \multirow{2}{*}{ HHI } & -0.094 & -0.478 & -0.106 & -0.131 & -0.148 & -0.054 \\
\hline & $(-0.34)$ & $(-0.35)$ & $(-0.38)$ & $(-0.70)$ & $(-0.54)$ & $(-0.29)$ \\
\hline Synchronous & 0.030 & 0.017 & 0.040 & 0.001 & 0.008 & 0.012 \\
\hline fundamentals & $(1.07)$ & $(0.72)$ & $(0.68)$ & $(0.06)$ & $(0.23)$ & $(1.30)$ \\
\hline \multirow[t]{2}{*}{ Intercept } & $-1.412 * * *$ & $-1.443 * * *$ & $1.206^{* *}$ & $-0.575^{* * *}$ & -0.085 & $2.797 * * *$ \\
\hline & $(-4.81)$ & $(-2.94)$ & $(2.04)$ & $(-4.03)$ & $(-1.48)$ & $(8.38)$ \\
\hline Year Dummy & Yes & No & Yes & Yes & No & Yes \\
\hline Industry Dummy & Yes & Yes & Yes & No & Yes & Yes \\
\hline $\mathrm{N}$ & 3946 & 3946 & 3946 & 7967 & 7967 & 7967 \\
\hline Adjusted $R^{2}$ & 0.319 & 0.224 & 0.315 & 0.286 & 0.232 & 0.295 \\
\hline
\end{tabular}




\section{Table 7. Excluding Observations}

This panel presents the regression results of ultimate ownership, analyst coverage and its interaction on stock return synchronicity, respectively for a sample that excludes zero analyst observations and a sample that excludes observations in 2008. All variables are defined in Appendix 1.Columns (1) and (4) presents the OLS results, Columns (2) and (5) presents the Fama and MacBeth (1973) panel results, and Columns (3) and (6) presents the 2SLS second stage result where the predicted analyst following value as the independent variable. Year/Industry dummies are included but not reported, and $t$-statistics are given in parentheses and computed using heteroskedasticity-robust standard errors clustered by firm/industry and year where appropriate (Petersen, 2009; Thompson, 2011). All continuous variables are winsorized at the top and bottom 1\%. $* * *, * *$, and $*$ denote significance at the $1 \%, 5 \%$, and $10 \%$ level, respectively.

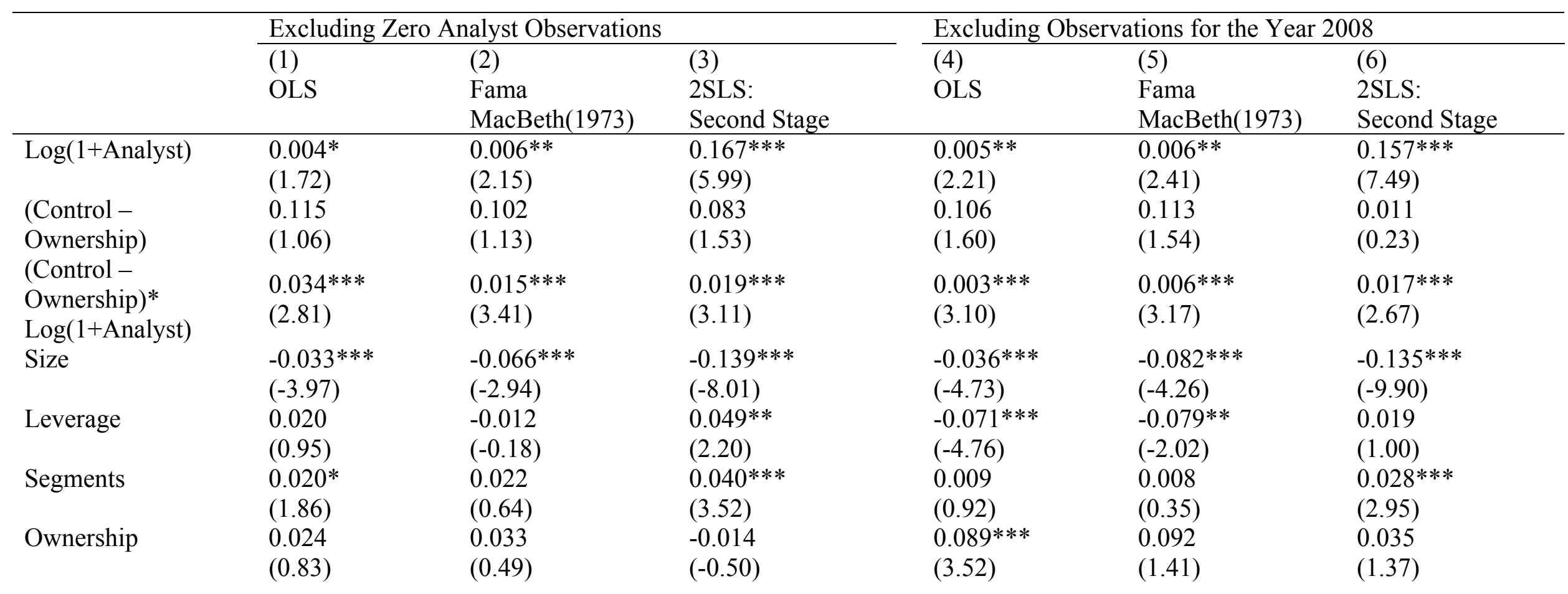




\begin{tabular}{|c|c|c|c|c|c|c|}
\hline Volume & $\begin{array}{l}0.068 * * * \\
(8.32)\end{array}$ & $\begin{array}{l}0.095 * * * \\
(4.11)\end{array}$ & $\begin{array}{l}0.039 * * * \\
(4.28)\end{array}$ & $\begin{array}{l}0.086 * * * \\
(11.84)\end{array}$ & $\begin{array}{l}0.115^{* * * *} \\
(5.88)\end{array}$ & $\begin{array}{l}0.057 * * * \\
(7.18)\end{array}$ \\
\hline Volatility & $\begin{array}{l}-5.248 * * * \\
(-17.45)\end{array}$ & $\begin{array}{l}-5.352 * * * \\
(-6.60)\end{array}$ & $\begin{array}{l}-3.446 * * * \\
(-8.80)\end{array}$ & $\begin{array}{l}-6.807 * * * \\
(-25.76)\end{array}$ & $\begin{array}{l}-7.162 * * * \\
(-10.62)\end{array}$ & $\begin{array}{l}-5.084 * * * \\
(-15.56)\end{array}$ \\
\hline Illiquidity & $\begin{array}{l}-2.408^{* * *} \\
(-8.25)\end{array}$ & $\begin{array}{l}-3.504 * * * \\
(-2.96)\end{array}$ & $\begin{array}{l}-3.365^{* * *} \\
(-10.39)\end{array}$ & $\begin{array}{l}-1.893 * * * \\
(-9.34)\end{array}$ & $\begin{array}{l}-3.769 * * * \\
(-3.70)\end{array}$ & $\begin{array}{l}-2.682 * * * \\
(-11.65)\end{array}$ \\
\hline$\%$ INST & $\begin{array}{l}-0.610^{* * *} \\
(-17.75)\end{array}$ & $\begin{array}{l}-0.560 * * * \\
(-5.82)\end{array}$ & $\begin{array}{l}-1.295^{* * *} \\
(-12.10)\end{array}$ & $\begin{array}{l}-0.559 * * * \\
(-15.64)\end{array}$ & $\begin{array}{l}-0.520 * * * \\
(-5.42)\end{array}$ & $\begin{array}{l}-1.183 * * * \\
(-14.28)\end{array}$ \\
\hline Investibility & $\begin{array}{l}-0.030 \\
(-1.64)\end{array}$ & $\begin{array}{l}-0.104^{*} \\
(-1.67)\end{array}$ & $\begin{array}{l}-0.048^{* * *} \\
(-2.60)\end{array}$ & $\begin{array}{l}-0.006 \\
(-0.38)\end{array}$ & $\begin{array}{l}-0.131 * * \\
(-2.13)\end{array}$ & $\begin{array}{l}-0.027 \\
(-1.58)\end{array}$ \\
\hline HHI & $\begin{array}{l}-0.042 \\
(-0.22)\end{array}$ & $\begin{array}{l}0.831 \\
(0.10)\end{array}$ & $\begin{array}{l}0.067 \\
(0.35)\end{array}$ & $\begin{array}{l}-0.060 \\
(-0.35)\end{array}$ & $\begin{array}{l}0.656 \\
(0.16)\end{array}$ & $\begin{array}{l}-0.014 \\
(-0.08)\end{array}$ \\
\hline $\begin{array}{l}\text { Synchronous } \\
\text { fundamentals }\end{array}$ & $\begin{array}{l}0.008 \\
(0.15)\end{array}$ & $\begin{array}{l}0.010 \\
(0.51)\end{array}$ & $\begin{array}{l}0.014 \\
(1.35)\end{array}$ & $\begin{array}{l}0.011 \\
(1.34)\end{array}$ & $\begin{array}{l}0.013 \\
(0.49)\end{array}$ & $\begin{array}{l}-0.021 \\
(1.29)\end{array}$ \\
\hline Intercept & $\begin{array}{l}-0.648^{* * *} \\
(-4.19)\end{array}$ & $\begin{array}{l}-0.682 \\
(-1.20)\end{array}$ & $\begin{array}{l}2.050^{* * *} \\
(4.98)\end{array}$ & $\begin{array}{l}-0.826^{* * *} \\
(-5.81)\end{array}$ & $\begin{array}{l}-0.676^{* * *} \\
(-3.31)\end{array}$ & $\begin{array}{l}1.726^{* * *} \\
(5.38)\end{array}$ \\
\hline Year Dummy & Yes & No & Yes & Yes & No & Yes \\
\hline Industry Dummy & Yes & Yes & Yes & Yes & Yes & Yes \\
\hline $\mathrm{N}$ & 7637 & 7637 & 7637 & 10497 & 10497 & 10497 \\
\hline Adjusted $R^{2}$ & 0.316 & 0.224 & 0.320 & 0.283 & 0.226 & 0.281 \\
\hline
\end{tabular}


Table8.Pyramids, Analyst Coverage and Stock Return Synchronicity

Panel A: Stock Return Synchronicity and Pyramidal Structure

This panel presents the summary statistics for the sample portfolios with and without Pyramidal Structure. Mean is the average across all firms and years, and the corresponding median is given in parentheses. All continuous variables are winsorized at the top and bottom 1\%. The last column (2)-(1) reports T-test (Wilcoxon-Mann-Whitney test) for the difference between Yes and No Pyramidal Structure portfolios. $* * *, * *$ and $*$ denote significance at $1 \%, 5 \%$, and $10 \%$ respectively.

\begin{tabular}{llll}
\hline & \multicolumn{2}{l}{ Pyramidal Structure } & \\
\cline { 2 - 3 } & $(1)$ & $(2)$ & $(2)-(1)$ \\
& No & Yes & T (WMW) Test \\
\hline$R^{2}$ & 0.356 & 0.365 & $2.33^{* * *}$ \\
& $(0.354)$ & $(0.361)$ & $(3.07 * * *)$ \\
Synch & -0.318 & -0.292 & $2.72 * * *$ \\
& $(-0.260)$ & $(-0.247)$ & $(3.07 * * *)$ \\
$\mathrm{N}$ & 1340 & 10573 & \\
\hline
\end{tabular}


Table8.Pyramids, Analyst Coverage and Stock Return Synchronicity

Panel B. Multivariate Regression

This panel presents the results of the effect of pyramids, analyst coverage and their interaction on stock synchronicity. The sample period is from 2005 to 2012. The dependent variable is Synch, a commonly used stock return synchronicity measure, calculated as $\log \left(R^{2} /\left(1-R^{2}\right)\right) . R^{2}$ is from regressions of the market model of return of the firm against the stock market index and industry index using weekly data. $\log (1+$ Analyst $)$ is the natural logarithm of one plus the number of analyst coverage for firm $i$ in year $t$. Size is the natural logarithm of market capitalization of firm $i$ at year $t$. Volume is the natural logarithm of trading volume of firm $i$ at year $t$. Volatility is the standard deviation of the stock return of firm $i$ at year $t$. \%INST is the ratio of mutual funds' holdings, measured as the aggregate number of shares held by mutual funds, scaled by shares outstanding of firm $i$ at year $t$. Investibility is the investibility measure of firm $i$ at year $t$. Column (1) presents the results from the OLS regression in which year and industry dummies are included but not reported. $t$-statistics are given in parentheses and computed using heteroskedasticity-robust standard errors clustered by firm and year (Petersen, 2009; Thompson, 2011).Column (2) presents Fama and MacBeth (1973) panel results. Industry dummies are included but not reported, and $t$-statistics are computed using heteroskedasticity-robust standard errors clustered by industry. All continuous variables are winsorized at the top and bottom $1 \%$. $^{* * *}$, **, and $*$ denote significance at the $1 \%, 5 \%$, and $10 \%$ level, respectively.

\begin{tabular}{lll}
\hline & $(1)$ & $(2)$ \\
& OLS & Fama and MacBeth(1973) \\
\hline Log(1+Analyst) & $0.022^{* * *}$ & $0.030^{* *}$ \\
Pyramids & $(2.90)$ & $(2.05)$ \\
& $0.017^{*}$ & 0.015 \\
Pyramids $*$ & $(1.81)$ & $(1.32)$ \\
Log(1+Analyst $)$ & $0.036^{* * *}$ & $0.043^{* * *}$ \\
Size & $(4.65)$ & $(2.79)$ \\
& $-0.035^{* * *}$ & $-0.077^{* * *}$ \\
Leverage & $(-5.03)$ & $(-4.05)$ \\
& $-0.086^{* * *}$ & $-0.096^{* *}$ \\
Segments & $(-6.30)$ & $(-2.53)$ \\
& 0.008 & 0.009 \\
Ownership & $(0.96)$ & $(0.41)$ \\
& $0.069^{* * *}$ & 0.065 \\
Volume & $(3.39)$ & $(1.28)$ \\
& $0.081^{* * *}$ & $0.107 * * *$ \\
Volatility & $(12.35)$ & $(5.64)$ \\
Illiquidity & $-6.238^{* * *}$ & $-6.531 * * *$ \\
& $(-25.93)$ & $(-9.83)$ \\
\%INST & $-1.913^{* * *}$ & $-3.802^{* * *}$ \\
Investibility & $(-10.91)$ & $(-4.17)$ \\
& $-0.607 * * *$ & $-0.555^{* * *}$ \\
& $(-18.87)$ & $(-6.20)$ \\
& -0.021 & $-0.141^{* *}$ \\
& &
\end{tabular}




\begin{tabular}{lll} 
& $(-1.29)$ & $(-2.35)$ \\
HHI & -0.106 & -0.191 \\
& $(-0.71)$ & $(-0.43)$ \\
Synchronous fundamentals & -0.009 & 0.011 \\
& $(1.20)$ & $(0.46)$ \\
Intercept & $-0.712^{* * *}$ & $-0.447^{* * *}$ \\
& $(-5.37)$ & $(-2.82)$ \\
Year Dummy & Yes & No \\
Industry Dummy & Yes & Yes \\
$\mathrm{N}$ & 11913 & 11913 \\
Adjusted $R^{2}$ & 0.334 & 0.230 \\
\hline
\end{tabular}


Table 9. Effect of Pyramids and Analyst Coverage on Stock Return Synchronicity: 2SLS

This table reports the 2SLS results of pyramids, analyst coverage and its interaction on stock return synchronicity First, a Tobit model is used to consider the endogenous determinants of analyst following. The predicted analyst following is then included as an independent variable in the second-stage regression to study its effect and its interaction with pyramids on stock return synchronicity. The sample period is from 2005 to 2012.In the first stage, the dependent variable is $\log (1+$ Analyst $)$, the natural logarithm of one plus the number of analyst coverage for firm $i$ in year $t$. The instruments for the endogenous variables include: CSI 300,an indicator for whether the firm is a constituent stock of CSI 300, a market index designed to reflect the stock performance in China; Industry Median Number of Analysts, measured as the natural logarithm of the median number of analysts for firms in the same industry as firm $i$ in year $t$; Industry Leader, an indicator for whether the firm is an industry leader, measured as whether its sales ranked as top $30 \%$ in its industry at year $t ; \log (M T B)$, measured as the natural logarithm of market-to-book equity ratio; Firm profitability, defined as earnings/total equities; Family Firm, a dummy variable which equals one if firm $i$ is ultimately owned by private entrepreneurs and zero otherwise. Statistics from tests for relevance and validity of instruments are reported in the bottom panel. All variables are winsorized at the top and bottom 1\%. All specifications contain year and industry dummies. Values of the $t$-statistics are in parentheses and are computed using heteroskedasticity-robust standard errors clustered by firm and year (Petersen, 2009; Thompson, 2011).***, **, and $*$ denote significance at the $1 \%, 5 \%$, and $10 \%$ level, respectively.

\begin{tabular}{|c|c|c|}
\hline & First Stage & Second Stage \\
\hline Dependent Variables & $\log (1+$ Analyst $)$ & Synch \\
\hline Predicted $\log (1+$ Analyst $)$ & & $\begin{array}{l}0.145^{* * *} \\
(7.01)\end{array}$ \\
\hline Pyramids & $\begin{array}{l}-0.292 * * * \\
(-11.01)\end{array}$ & $\begin{array}{l}0.017 \\
(0.79)\end{array}$ \\
\hline $\begin{array}{l}\text { Pyramids * } \\
\text { Predicted Log }(1+\text { Analyst })\end{array}$ & & $\begin{array}{l}0.046^{* * * *} \\
(4.32)\end{array}$ \\
\hline CSI 300 & $\begin{array}{l}0.097 * * * \\
(3.35)\end{array}$ & \\
\hline $\begin{array}{l}\text { Industry Median Number } \\
\text { of Analvst }\end{array}$ & $0.321 * * *$ & \\
\hline Industry Leader & $\begin{array}{l}0.078 * * * \\
(3.40)\end{array}$ & \\
\hline $\log (\mathrm{MTB})$ & $\begin{array}{l}-0.168^{* * *} \\
(-10.49)\end{array}$ & \\
\hline Firm profitability & $\begin{array}{l}0.557 * * * \\
(10.83)\end{array}$ & \\
\hline Firm size & $\begin{array}{l}0.594 * * * \\
(30.58)\end{array}$ & $\begin{array}{l}-0.144 * * * \\
(-11.38)\end{array}$ \\
\hline Leverage & $\begin{array}{l}-0.103 * * \\
(-2.21)\end{array}$ & $\begin{array}{l}0.008 \\
(0.44)\end{array}$ \\
\hline Segments & $-0.101 * * *$ & $0.027 * * *$ \\
\hline
\end{tabular}




\begin{tabular}{lll} 
& $(-4.68)$ & $(3.10)$ \\
Ownership & 0.038 & $0.045^{* *}$ \\
Volume & $(0.74)$ & $(2.23)$ \\
& $0.134^{* * *}$ & $0.053^{* * *}$ \\
Volatility & $(7.93)$ & $(7.52)$ \\
& $-7.255^{* * *}$ & $-4.500^{* * *}$ \\
Illiquidity & $(-11.23)$ & $(-15.49)$ \\
& $5.275^{* * *}$ & $-2.763^{* * *}$ \\
\%INST & $(11.48)$ & $(-13.99)$ \\
& $3.811^{* * *}$ & $-1.260^{* * *}$ \\
Investibility & $(49.76)$ & $(-17.43)$ \\
& $0.114^{* * *}$ & $-0.041^{* *}$ \\
HHI & $(2.80)$ & $(-2.52)$ \\
& 0.021 & -0.068 \\
Synchronous fundamentals & $(0.47)$ & $(-0.45)$ \\
& 0.056 & 0.020 \\
Intercept & $(0.88)$ & $(1.38)$ \\
& $-14.338^{* * *}$ & $1.967 * * *$ \\
Year Dummy & $(-37.87)$ & $(6.88)$ \\
Industry Dummy & Yes & Yes \\
N & Yes & Yes \\
Adjusted $R^{2}$ & 11913 & 11913 \\
\hline Tests of Exogeneity, Relevance and Validity of Instruments \\
\hline Shea Partial $R^{2}:$ First Stage & 0.349 & 0.335 \\
F-statistic: First Stage & $25.173^{* * *}$ & \\
Anderson-Rubin F-statistic & & $34.572^{* * *}$ \\
Hansen $J$-statistic & & 1.108 \\
\hline
\end{tabular}


Table 10. Lead-Lag Relationship Between Portfolio Returns

A vector autoregression (VAR) is estimated for weekly portfolio returns sorted by (control - ownership) and analyst coverage. F refers a portfolio of firms with few analysts who cover them and $\mathrm{M}$ refers to a portfolio of firms with many analysts who cover them. The model specification is:

$$
\begin{aligned}
& R_{F, t}=\alpha_{F}+\sum_{k=1}^{K} \beta_{F, t-k} R_{F, t-k}+\sum_{k=1}^{K} \beta_{M, t-k} R_{M, t-k}+\mu_{F, t}, \\
& R_{M, t}=\alpha_{M}+\sum_{k=1}^{K} \gamma_{F, t-k} R_{F, t-k}+\sum_{k=1}^{K} \gamma_{M, t-k} R_{M, t-k}+\mu_{M, t},
\end{aligned}
$$

Where $R_{F, t}$ and $R_{M, t}$ are weekly returns of the few-analyst $(F)$ portfolio and many-analyst $(M)$ portfolio and $K$ is the number of lags. Estimations for models with $K=1,2$ and 3 are reported. Adjusted $R^{2}$ refers to the adjusted coefficient of determination. The Wald statistic tests the null hypothesis: $\sum_{k=1}^{K} \beta_{M, k}>\sum_{k=1}^{K} \gamma_{F, k}$.***,

\begin{tabular}{|c|c|c|c|c|c|}
\hline \multirow[t]{2}{*}{ Subsample } & \multirow[t]{2}{*}{ Dependent } & \multicolumn{2}{|c|}{ Independent } & \multirow{2}{*}{$\begin{array}{l}\text { Adjusted } \\
\text { R2 }\end{array}$} & \multirow[t]{2}{*}{ Wald test } \\
\hline & & $R_{F, t}$ & $R_{M, t}$ & & \\
\hline \multicolumn{6}{|c|}{1 Lag Regression } \\
\hline \multirow{2}{*}{$\begin{array}{l}\text { Firms with } \\
\text { larger } \\
\text { separation }\end{array}$} & $R_{F, t}$ & $\begin{array}{l}-0.107 \\
(-1.00)\end{array}$ & $\begin{array}{l}0.287^{* *} \\
(2.14)\end{array}$ & 0.020 & $15.83 * * *$ \\
\hline & $R_{M, t}$ & $\begin{array}{l}-0.163 \\
(-1.49)\end{array}$ & $\begin{array}{l}0.246^{* * * *} \\
(2.28)\end{array}$ & 0.013 & \\
\hline \multirow{2}{*}{$\begin{array}{l}\text { Firms with } \\
\text { smaller } \\
\text { separation }\end{array}$} & $R_{F, t}$ & $\begin{array}{l}-0.048 \\
(-0.49)\end{array}$ & $\begin{array}{l}0.159 * \\
(1.77)\end{array}$ & 0.009 & $4.57 * *$ \\
\hline & $R_{M, t}$ & $\begin{array}{l}-0.050 \\
(-0.59)\end{array}$ & $\begin{array}{l}0.091 \\
(0.92)\end{array}$ & 0.002 & \\
\hline \multicolumn{6}{|c|}{2 Lag Regression } \\
\hline \multirow[t]{2}{*}{$\begin{array}{l}\text { Firms with } \\
\text { larger } \\
\text { separation }\end{array}$} & $R_{F, t}$ & $\begin{array}{l}-0.043 \\
(-0.92)\end{array}$ & $\begin{array}{l}0.364 * * \\
(2.09)\end{array}$ & 0.037 & $24.69 * * *$ \\
\hline & $R_{M, t}$ & $\begin{array}{l}-0.251 \\
(-1.08)\end{array}$ & $\begin{array}{l}0.490 * * * \\
(2.61)\end{array}$ & 0.038 & \\
\hline \multirow{2}{*}{$\begin{array}{l}\text { Firms with } \\
\text { smaller } \\
\text { separation }\end{array}$} & $R_{F, t}$ & $\begin{array}{l}0.079 \\
(0.42)\end{array}$ & $\begin{array}{l}0.109 * \\
(1.88)\end{array}$ & 0.019 & $3.79 *$ \\
\hline & $R_{M, t}$ & $\begin{array}{l}-0.073 \\
(0.73) \\
\end{array}$ & $\begin{array}{l}0.232 \\
(1.15) \\
\end{array}$ & 0.017 & \\
\hline \multicolumn{6}{|c|}{3 Lag Regression } \\
\hline $\begin{array}{l}\text { Firms with } \\
\text { larger } \\
\text { separation }\end{array}$ & $R_{F, t}$ & $\begin{array}{l}-0.005 \\
(-0.46)\end{array}$ & $\begin{array}{l}0.415 * * \\
(2.17)\end{array}$ & 0.048 & $31.05 * * *$ \\
\hline
\end{tabular}
$* *$, and $*$ denote significance at the $1 \%, 5 \%$, and $10 \%$ level, respectively. 


\begin{tabular}{llllll} 
& $R_{M, t}$ & -0.292 & $0.604^{* *}$ & 0.046 & \\
& & $(-1.42)$ & $(2.03)$ & & \\
Firms with & $R_{F, t}$ & 0.088 & $0.116^{*}$ & 0.032 & 1.21 \\
smaller & & $(0.41)$ & $(1.73)$ & & \\
separation & & & & & \\
& $R_{M, t}$ & -0.054 & 0.165 & 0.025 & \\
& & $(-0.72)$ & $(1.18)$ & & \\
\hline
\end{tabular}


Appendix 1. Definition of Variables

\begin{tabular}{ll}
\hline Variable & Definition \\
\hline Synch & $\begin{array}{l}\text { A commonly used stock return synchronicity measure, } \\
\text { calculated aslog }\left(R^{2} /\left(1-R^{2}\right)\right) \text {. }\end{array}$ \\
$R^{2}$ is the $R$-square from the market model of regressing \\
the stock return of a firm against the stock market \\
index and industry index ina specific year.
\end{tabular}


Industry Median Number of Analysts

Industry Leader

$\log (\mathrm{MTB})$

Firm profitability
The natural logarithm of the median number of analysts for firms in the same industry as the firm in question. An indicator for industry leadership, measured as whether a firm's sales ranked as top $30 \%$ in its industry in a specific year.

The natural logarithm of market-to-book equity ratio of a firm in a specific year.

The ratio of earnings to equity (ROE) of a firm in a specific year. 


\section{Appendix 2. Main Control Variables}

This appendix presents the summary statistics for the main control variables in this study. The variables are defined in Appendix 1. All continuous variables are winsorized at the top and bottom $1 \%$.

\begin{tabular}{|c|c|c|c|c|c|c|c|c|}
\hline & Number & Mean & Median & Std. & Min & Q1 & Q3 & Max \\
\hline Synch & 11913 & -0.295 & -0.249 & 0.409 & -5.690 & -0.498 & -0.029 & 0.861 \\
\hline$R^{2}$ & 11913 & 0.364 & 0.360 & 0.166 & 0.000 & 0.241 & 0.483 & 0.879 \\
\hline Analyst Following & 11913 & 9.885 & 2.000 & 17.064 & 0.000 & 0.000 & 12.000 & 177.000 \\
\hline $\log (1+$ Analyst $)$ & 11913 & 1.430 & 1.099 & 1.369 & 0.000 & 0.000 & 2.565 & 4.407 \\
\hline Pyramids & 11913 & 0.888 & 1.000 & 0.316 & 0.000 & 1.000 & 1.000 & 1.000 \\
\hline Control - Ownership & 11913 & 0.061 & 0.000 & 0.084 & 0.000 & 0.000 & 0.116 & 0.445 \\
\hline Size & 11913 & 21.926 & 21.816 & 1.090 & 19.809 & 21.187 & 22.554 & 25.193 \\
\hline Leverage & 11913 & 0.508 & 0.505 & 0.245 & 0.057 & 0.344 & 0.646 & 1.644 \\
\hline Segments & 11913 & 1.161 & 1.000 & 0.375 & 1.000 & 1.000 & 1.000 & 3.000 \\
\hline Ownership & 11913 & 0.321 & 0.299 & 0.175 & 0.027 & 0.182 & 0.444 & 0.740 \\
\hline Volume & 11913 & 22.990 & 23.065 & 1.170 & 20.082 & 22.263 & 23.766 & 25.657 \\
\hline Volatility & 11913 & 0.068 & 0.064 & 0.022 & 0.030 & 0.052 & 0.082 & 0.131 \\
\hline Illiquidity & 11913 & 0.026 & 0.014 & 0.031 & 0.000 & 0.006 & 0.033 & 0.164 \\
\hline$\%$ INST & 11913 & 0.079 & 0.014 & 0.131 & 0.000 & 0.000 & 0.100 & 0.609 \\
\hline Investibility & 11913 & 0.647 & 0.617 & 0.274 & 0.122 & 0.414 & 0.984 & 1.000 \\
\hline HHI & 11913 & 0.075 & 0.046 & 0.076 & 0.017 & 0.034 & 0.078 & 0.370 \\
\hline Synchronous fundamentals & 11913 & 0.209 & 0.235 & 0.448 & -0.824 & -0.122 & 0.565 & 0.982 \\
\hline CSI 300 & 11913 & 0.190 & 0.000 & 0.392 & 0.000 & 0.000 & 0.000 & 1.000 \\
\hline $\begin{array}{l}\text { Industry Median Number of } \\
\text { Analyst }\end{array}$ & 11913 & 1.242 & 1.099 & 0.821 & 0.000 & 0.693 & 1.869 & 3.784 \\
\hline Industry Leader & 11913 & 0.325 & 0.000 & 0.468 & 0.000 & 0.000 & 1.000 & 1.000 \\
\hline $\log (\mathrm{MTB})$ & 11646 & 1.013 & 0.955 & 0.708 & -0.381 & 0.494 & 1.470 & 3.061 \\
\hline Firm profitability & 11912 & 0.055 & 0.066 & 0.184 & -1.100 & 0.024 & 0.113 & 0.698 \\
\hline
\end{tabular}




\section{Appendix 3: Correlation}

This table presents the correlation matrix for the main variables in this study. All variables are defined in Appendix 1. The upper triangle presents the Spearman correlation coefficient. The lower triangle presents the Pearson correlation coefficient. $* * * * *$, and $*$ denote significance at the $1 \%, 5 \%$ and $10 \%$ level, respectively.

\begin{tabular}{|c|c|c|c|c|c|c|c|c|c|c|c|c|c|c|c|}
\hline & (1) & (2) & (3) & (4) & (5) & (6) & (7) & (8) & (9) & (10) & (11) & (12) & (13) & (14) & (15) \\
\hline \multicolumn{16}{|l|}{ (1)Synch } \\
\hline & & $0.065^{* * *}$ & $-0.033^{* * *}$ & $0.019 * * *$ & $0.043 * * *$ & $-0.020^{* *}$ & -0.005 & 0.062 & $0.065^{* * *}$ & $-0.147 * * *$ & $-0.197 * * *$ & 0.015 & $0.126^{* * *}$ & $0.047 * * *$ & $0.045^{* * * *}$ \\
\hline \multicolumn{16}{|c|}{ (2) $\log (1+$ Analyst $)$} \\
\hline & $0.067 * * *$ & & $-0.033 * * *$ & $-0.088 * * *$ & $0.661 * * *$ & $-0.117 * * *$ & $-0.057 * * *$ & $0.210^{* * *}$ & $0.434^{* * *}$ & $-0.205 * * *$ & $-0.557^{* * * *}$ & $0.729 * * *$ & 0.000 & $0.066 * * *$ & $0.149 * * *$ \\
\hline \multicolumn{16}{|c|}{ (3) Control - Ownership } \\
\hline & $-0.016^{* * *}$ & $-0.003^{* * *}$ & & $0.242 * * *$ & -0.037 & 0.029 & -0.008 & -0.488 & -0.037 & 0.054 & $0.044^{* * *}$ & -0.038 & 0.022 & -0.055 & -0.035 \\
\hline \multicolumn{16}{|l|}{ (4) Pyramids } \\
\hline & $0.016^{* * *}$ & $-0.080^{* * *}$ & $0.213 * * *$ & & 0.042 & 0.174 & 0.062 & -0.063 & 0.060 & 0.046 & -0.093 & -0.059 & 0.152 & -0.007 & -0.020 \\
\hline \multicolumn{16}{|l|}{ (5) Size } \\
\hline & $0.068^{* * *}$ & $0.673 * * *$ & -0.020 & 0.054 & & $-0.035^{* *}$ & -0.018 & 0.226 & $0.761 * * *$ & -0.087 & $-0.790 * * *$ & 0.612 & 0.096 & 0.100 & 0.152 \\
\hline (6)Leverage & $-0.076 * * *$ & $-0.146^{* * * *}$ & 0.037 & 0.168 & -0.072 & & 0.007 & -0.074 & 0.016 & $0.093 * * *$ & $-0.020^{* *}$ & $-0.104 * * *$ & $0.133^{* * *}$ & -0.020 & 0.022 \\
\hline (7)Segments & -0.002 & $-0.055^{* * *}$ & 0.000 & 0.062 & -0.014 & 0.009 & & 0.005 & -0.002 & 0.017 & 0.012 & $-0.034 * * *$ & 0.019 & 0.031 & -0.016 \\
\hline (8)Ownership & 0.067 & $0.204 * * *$ & -0.435 & -0.053 & 0.261 & -0.110 & 0.009 & & 0.017 & -0.102 & -0.072 & 0.171 & $-0.290 * * *$ & 0.082 & 0.080 \\
\hline \multicolumn{16}{|l|}{ (9)Volume } \\
\hline & $0.103 * * *$ & $0.456^{* * *}$ & -0.032 & 0.042 & 0.771 & -0.048 & -0.007 & 0.035 & & $0.203 * * *$ & $-0.661 * * *$ & $0.372 * * *$ & $0.314 * * *$ & 0.054 & 0.089 \\
\hline (10)Volatility & $-0.133^{* * *}$ & $-0.217^{* * *}$ & 0.042 & 0.049 & -0.097 & $0.105^{* * *}$ & 0.020 & -0.102 & $0.189 * * *$ & & 0.382 & $-0.121^{* * *}$ & $-0.143 * *$ & -0.051 & -0.113 \\
\hline
\end{tabular}




\begin{tabular}{|c|c|c|c|c|c|c|c|c|c|c|c|c|c|c|c|}
\hline (11)Illiquidity & $-0.185^{* * * *}$ & $-0.435 * * *$ & $0.041^{* * *}$ & -0.039 & $-0.652^{* * *}$ & 0.109 & 0.010 & -0.058 & $-0.652^{* * * *}$ & 0.259 & & $-0.474 * *$ & -0.504 & $-0.092 *$ & -0.167 \\
\hline $\begin{array}{l}\text { (12)\%INST } \\
\text { (13)Investibility }\end{array}$ & $\begin{array}{l}-0.118 * * * \\
0.124 * * *\end{array}$ & $\begin{array}{l}0.580^{* * *} \\
0.019 \\
0.083^{* * *}\end{array}$ & $\begin{array}{l}-0.004 \\
-0.007\end{array}$ & $\begin{array}{l}-0.043 \\
0.151\end{array}$ & $\begin{array}{l}0.461 \\
0.085\end{array}$ & $\begin{array}{l}-0.090^{* * *} \\
0.112^{* * *}\end{array}$ & $\begin{array}{l}-0.028^{* *} \\
0.017 \\
0.026\end{array}$ & $\begin{array}{l}0.102 \\
-0.303 * * *\end{array}$ & $\begin{array}{l}0.246^{* * *} \\
0.326^{* * *}\end{array}$ & $\begin{array}{l}0.010^{* * *} \\
-0.155^{* * * *}\end{array}$ & $\begin{array}{l}-0.245 * * * \\
-0.451 * *\end{array}$ & -0.154 & -0.070 & $\begin{array}{l}0.055 * * * \\
-0.010\end{array}$ & $\begin{array}{l}0.097^{* * *} \\
0.029^{* *}\end{array}$ \\
\hline (14) $\mathrm{HHI}$ & 0.040 & $0.083 * * *$ & -0.010 & -0.035 & 0.119 & -0.008 & 0.026 & 0.073 & 0.094 & 0.027 & & $0.049 * * *$ & -0.031 & & $0.182^{*}$ \\
\hline $\begin{array}{l}\text { (15)Synchronous } \\
\text { fundamentals }\end{array}$ & $0.040^{*}$ & $0.158^{* * *}$ & -0.026 & -0.012 & 0.165 & 0.020 & -0.015 & 0.080 & 0.103 & -0.110 & -0.121 & 0.056 & 0.036 & $0.095 * *$ & \\
\hline
\end{tabular}


Figure 1. Ownership Structure of China Construction

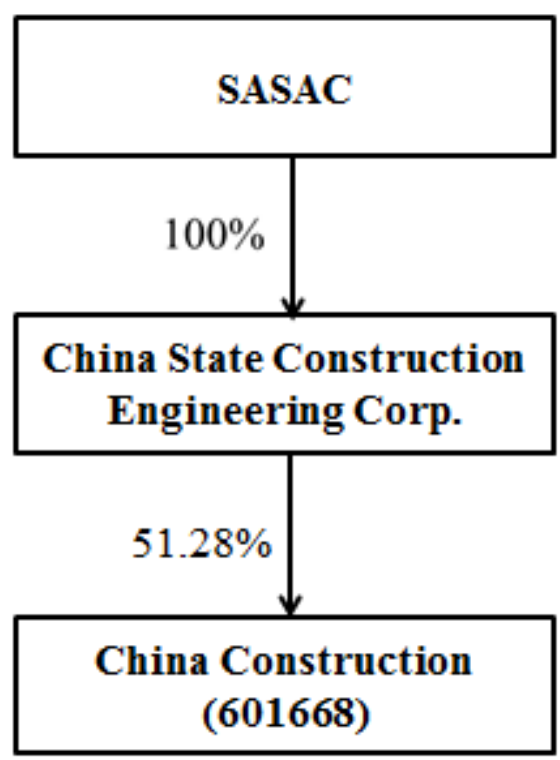

Note: This figure illustrates the ultimate ownership structure of China Construction. SASAC holds 100 percent of the votes as well as shares of China State Construction Engineering Corp., which in turn owns 51.28 percent of China Construction. 


\section{Figure 2. Ownership Structure of Orient Zirconic}

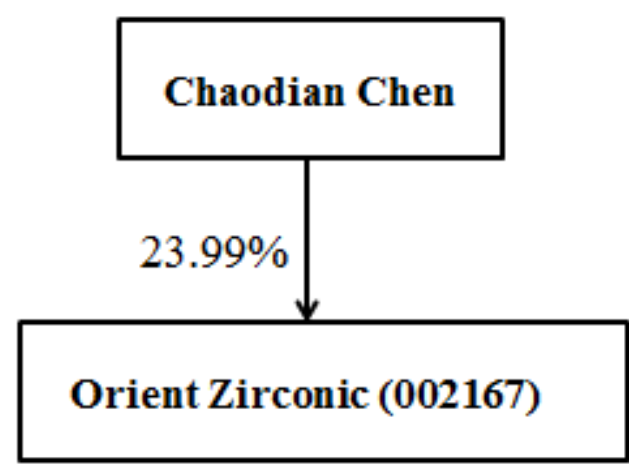

Note: This figure illustrates the ultimate ownership structure of Orient Zirconic. Based on the 10 percent rule, control is assigned to Chaodian Chen. Here, the ultimate owner owns and controls the listed firm directly. The ultimate ownership and control rights are both $23.99 \%$. 
Figure 3. Ownership Structure of Nanjing Iron \& Steel Co., Ltd.

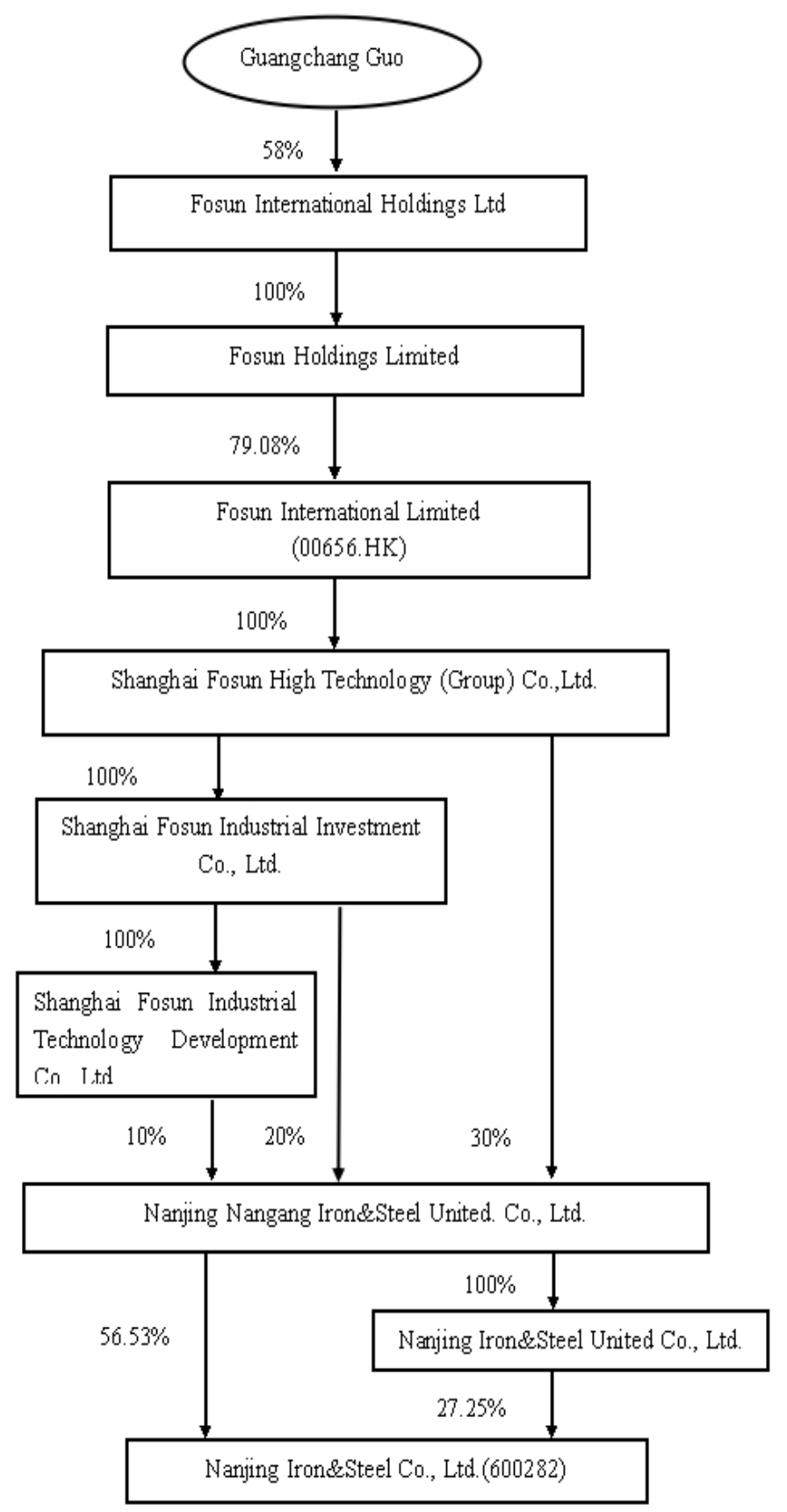

Note: This figure illustrates the ultimate ownership structure of Nanjing Iron \& Steel Co., Ltd. The firm is ultimately controlled by Guangchang Guo., who owns $23.06 \%$ of the cash flow rights and $58 \%$ of the voting rights in the firm through a pyramid ownership structure. 
Figure 4. The Shanghai Composite Index

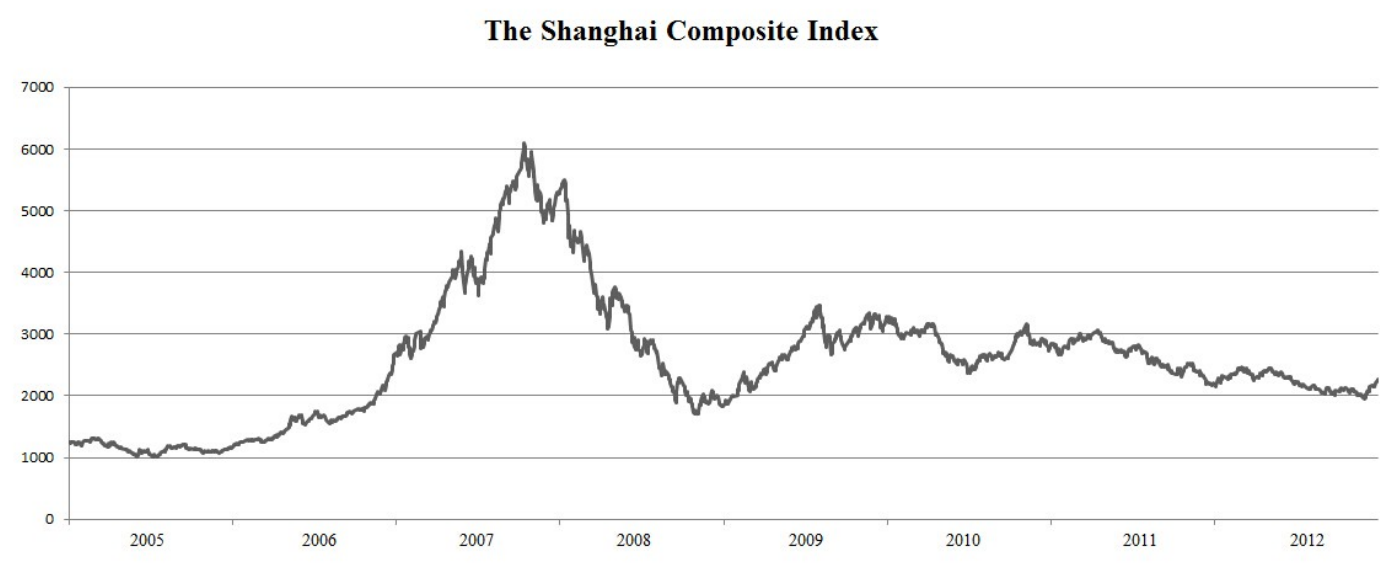

Note: This figure illustrates the Shanghai Composite Index during the period 1 January 2005 to 31 December 2012. 